\title{
O gênero Glandularia J.F. Gmel. (Verbenaceae) no Rio Grande do Sul, Brasil ${ }^{1}$
}

\author{
Verônica Aydos Thode ${ }^{2,3}$ e Lilian Auler Mentz ${ }^{2}$
}

Recebido em 4/06/2009. Aceito em 31/03/2010

RESUMO - (O gênero Glandularia J.F. Gmel. (Verbenaceae) no Rio Grande do Sul, Brasil). Este trabalho consiste no levantamento florístico do gênero Glandularia J.F. Gmel. (Verbenaceae) no estado do Rio Grande do Sul, Brasil. O gênero possui cerca de 80 espécies distribuídas nas regiões subtropicais e temperadas da América do Sul e América do Norte. Para realizar este estudo foram feitas viagens de coleta, revisão bibliográfica e de herbários. Glandularia está representado no Estado por 27 espécies, sendo que seis delas são primeira citação de ocorrência. São apresentadas chave de identificação, descrições, ilustrações e observações.

Palavras-chave: Glandularia, Verbenaceae, florística, Rio Grande do Sul

ABSTRACT - (The genus Glandularia J.F. Gmel. (Verbenaceae) in Rio Grande do Sul, Brazil). This paper consists of a floristic study of Glandularia J.F. Gmel. (Verbenaceae) at Rio Grande do Sul state, Brazil. The genus has about 80 species which occur in subtropical and temperate regions of South America and North America. Field collections, bibliographic, and herbaria revision were made to accomplish this study. Glandularia is represented in the State by 27 species, and six of them are recorded for the first time. A species key, descriptions, illustrations, and comments are presented.

Key words: Glandularia, Verbenaceae, floristics, Rio Grande do Sul

\section{Introdução}

Verbenaceae J. St.-Hil. possui cerca de 34 gêneros e 1.200 espécies que ocorrem principalmente nas Américas, com apenas dois gêneros (Chascanum E. Mey. e Coelocarpum Balf. f.) representados exclusivamente no Velho Mundo (Atkins 2004). O gênero Glandularia J.F. Gmel. (Verbeneae) reúne cerca de 80 espécies distribuídas nas regiões subtropicais e temperadas da América do Sul e América do Norte, estendendo-se desde o sul do Canadá até o norte da Patagônia, com distribuição disjunta (Solbrig 1968; Troncoso 1974; Peralta \& Thode 2010). A maioria das espécies atualmente aceita como Glandularia foi descrita como Verbena L. Estes gêneros diferem principalmente por Glandularia possuir o par superior de estames com ou sem apêndice no conectivo, este último sempre ultrapassado pelas tecas; estilete três ou mais vezes o comprimento do ovário; cálice maduro geralmente mais comprido que as clusas, com lacínias coniventes ou contortas; corola hipocrateriforme; inflorescências em monobótrios ou pleiobótrios heterotéticos de uma a três florescências; caule com clorênquima cortical em uma banda contínua e número cromossômico igual a 5 e seus múltiplos. Verbena possui o par superior de estames sem apêndice no conectivo, este último não ultrapassado pelas tecas; estilete até três vezes o comprimento do ovário; cálice maduro geralmente do mesmo comprimento que as clusas; corola infundibuliforme; inflorescências em pleiobótrios heterotéticos de três a muitas florescências; caule com clorênquima cortical em uma banda descontínua com colunas de colênquima e esclerênquima nos ângulos e número cromossômico igual a sete e seus múltiplos
(Schnack \& Covas 1944, 1964; Umber 1979; Botta 1989; O'Leary \& Peralta 2007; O'Leary et al. 2007). Para todos os caracteres morfológicos existem exceções e caracteres intermediários são encontrados em ambos os gêneros. Estudos filogenéticos abrangendo o complexo Verbena (Verbena L., Glandularia J.F. Gmel. e Junellia Moldenke), verificaram que Verbena e Glandularia formavam grupos monofiléticos e Junellia era parafilética, com dois clados separados, e ancestral dentro do complexo (Yuan \& Olmstead 2008). Um novo gênero, Mulgureae N. O'Leary \& P. Peralta, foi então criado para abranger as espécies de um dos clados de Junellia (O'Leary et al. 2009).

O presente trabalho tem como objetivos identificar, descrever, ilustrar e apresentar comentários sobre as espécies de Glandularia que ocorrem no Rio Grande do Sul, ressaltando a ocorrência das mesmas no Estado.

\section{Material e métodos}

O estudo florístico do gênero Glandularia no Rio Grande do Sul foi realizado de acordo com a metodologia clássica. Foram analisados exemplares depositados nos seguintes herbários: HAS, HURG, ICN, MBM, MPUC, PACA, SMDB, SI e SP cujas siglas seguem Holmgren et al. (2008). Foram também observadas as coleções dos herbários CNPO, HERULBRA, HUCS, HUI e UNILASALLE, não registrados até a data de publicação da obra consultada. Foram analisados exemplares digitalizados e tipos quando possível, além de revisão da literatura. Viagens de coleta foram realizadas por todas as regiões fisiográficas do Rio Grande do Sul. O material coletado foi herborizado e incorporado ao Herbário ICN. A terminologia foi baseada em Stearn (2000), Font Quer (1977) e Martínez \& Múlgura (1996). A grafia dos nomes dos autores foi baseada em Brummitt \& Powell (1992). As regiões fisiográficas mencionadas para o Estado estão de acordo com Fortes (1959). A listagem completa dos materiais examinados pode ser obtida com a primeira autora.

\footnotetext{
Parte da Dissertação de Mestrado da primeira Autora

2 Universidade Federal do Rio Grande do Sul, Instituto de Biociências, Departamento de Botânica, Porto Alegre, Rio Grande do Sul, Brasil

3 Autor para correspondência: veronicathode@hotmail.com
} 


\section{Resultados e discussão}

Glandularia J.F. Gmel., Syst. Veg 2(2): 920.1792.

Ervas ou subarbustos perenes, eretos, prostrados ou rasteiros, radicantes nos nós ou não, com ramos floríferos ascendentes. Plantas subglabras a pilosas, com tricomas tectores e glandulares. Caule quadrangular ou subquadrangular. Folhas opostas, inteiras, lobadas ou pinatissectas, sésseis ou pecioladas; lâmina decurrente no pecíolo ou no caule. Inflorescências em monobótrios ou pleiobótrios heterotéticos com 1 ou mais pares de paracládios simples, menos comumente trímeros ou tetrâmeros; florescências em espigas multifloras ou paucifloras, umbeliformes, cilíndricas ou ovóides na antese, com raque alongada ou não na frutificação. Brácteas lanceoladas, oval-lanceoladas ou linear-lanceoladas, com margem ciliada. Flores gamopétalas, levemente zigomorfas, monoclinas, sésseis. Cálice cilíndrico-tubular, com costelas freqüentemente evidentes; lacínias 5, desiguais, triangulares, triangular-lanceoladas, lanceoladas, subuladas ou mucronadas, coniventes ou contortas no fruto; cálice persistente no fruto. Corola hipocrateriforme ou infundibuliforme, lilás, roxa, branca, vermelha, rosa ou azul, externamente glabra ou pilosa e com tricomas moniliformes na fauce; limbo pentalobado com lobos desiguais. Estames 4, didínamos, epipétalos, o par superior com ou sem apêndices conectivais que superam ou não as tecas, inclusos ou exsertos; anteras ditecas. Ovário súpero, gamocarpelar, bicarpelar, tetralocular, lóculos monospérmicos; estilete terminal, filiforme, em geral pelo menos três vezes mais comprido do que o ovário; estigma bilobado. Fruto esquizocárpico formado por 4 clusas unisseminadas. Clusas com ápice agudo a obtuso, base alargada ou não, face ventral papilosa ou lisa, face dorsal geralmente reticulada na porção superior e estriada na inferior.
Aspectos morfológicos relevantes

Inflorescências-As inflorescências foram estudadas em Glandularia por Martínez \& Múlgura (1996) com base na terminologia desenvolvida por Troll \& Weberling (Troll 1950, 1957, 1964, 1969; Weberling 1961, 1965, 1985). O gênero apresenta inflorescências do tipo monobótrio (composto por uma florescência) ou pleiobótrio (composto por mais de uma florescência) heterotético (possui uma florescência principal) com um ou mais pares de paracládios (formados pelas florescências laterais) simples, trímeros (Glandularia corymbosa (Ruiz \& Pav.) O'Leary \& P. Peralta) ou tetrâmeros (Glandularia lobata (Vell.) P. Peralta \& Thode). As florescências podem ser espigas multifloras ou menos comumente paucifloras, umbeliformes, cilíndricas ou ovóides na antese, com raque alongada ou não na frutificação.

Clusas - $\mathrm{O}$ fruto é do tipo esquizocarpo, formado por quatro partes que se separam na maturação. Estas partes foram aqui denominadas de clusas. Outro nome empregado para estas estruturas é mericarpo.

Tricomas - São encontrados tricomas simples ou glandulares. Os tricomas simples são geralmente pluricelulares e unisseriados, ocorrendo nas partes aéreas. Na fauce da corola são encontrados tricomas moniliformes, que também são tricomas simples, pluricelulares e unisseriados, formados por células arredondadas (Fig. 87). Os tricomas glandulares podem ser pedicelados ou subsésseis. Estes últimos são muitas vezes referidos na literatura como pateliformes e ocorrem principalmente no cálice e brácteas, apresentando aspecto arredondado-achatado, sendo geralmete escuros.

Apêndice conectival - Algumas espécies possuem o par superior de estames providos de apêndices glandulares no conectivo, na face dorsal da antera, que podem ser vestigiais ou bem desenvolvidos. Eles superam as tecas ou não, podendo ser exsertos ou inclusos. Estes apêndices podem ser encontrados também em Junellia. As espécies de Verbena não os possuem.

Chave para identificação das espécies de Glandularia no estado do Rio Grande do Sul

1. Folhas pinatissectas a pinatipartidas

2. Pedúnculo das florescências com tricomas tectores antrorsos

3. Folhas sésseis; corola infundibuliforme, 4,1-7 mm compr., externamente pilosa; sem apêndices conectivais ou estes vestigiais

3. Folhas pecioladas; corola hipocrateriforme, 7-18 mm compr., externamente glabra; com apêndices conectivais bem desenvolvidos

4. Folhas trissectas, podendo ter os segmentos partidos ou não

4. Folhas com 3 a 5 lobos divididos em 2 ou mais segmentos

5. Par superior de estames com apêndices conectivais inclusos, que não superam as tecas 1. G. aristigera

5. Par superior de estames com apêndices conectivais exsertos, que superam as tecas...... 24. G. tenera

2. Pedúnculo das florescências com tricomas tectores patentes ou retrorsos

6. Cálice hirto, com tricomas tectores e tricomas glandulares pedicelados

7. Cálice 7-8 mm compr.; tubo da corola 12-15 mm compr., limbo 9-12 mm diâm. 2. G. catharinae

7. Cálice 4-4,5 mm compr.; tubo da corola 4-5 mm compr., limbo $2 \mathrm{~mm}$ diâm. 9. G. jordanensis

6. Cálice pubescente a estrigoso, com tricomas tectores e tricomas glandulares subsésseis

8. Corola externamente glabra. 23. G. subincana

8. Corola externamente pilosa 
9. Cálice com tricomas tectores antrorsos, mais evidentes sobre as costelas

9. Cálice com tricomas tectores retrorsos e patentes, bem distribuídos 27. G. tomophylla

1. Folhas inteiras ou lobadas

10. Corola com tricomas glandulares externamente

11. Par superior de estames sem apêndices conectivais

12. Pedúnculo das florescências com tricomas tectores retrorsos e poucos tricomas glandulares pedicelados 6.G. hasslerana

12. Pedúnculo das florescências com tricomas tectores e glandulares pedicelados patentes e antrorsos ou em várias direções, sendo a maioria patentes

13. Folhas com margem crenada; cálice 9-10 mm compr.

13. G. nana

13. Folhas com margem dentada, ou incisa; cálice $12-16 \mathrm{~mm}$ compr.

14. Corola branca, tubo 20-25 mm compr., limbo 15-17 mm diâm.; estilete $21 \mathrm{~mm}$ compr.

16. G. platensis

14. Corola rosa a lilás, tubo 18-20 mm compr., limbo 8-12 mm diâm.; estilete $15-17 \mathrm{~mm}$ compr

25. G. tessmannii

11. Par superior de estames com apêndices conectivais

15. Cálice com tricomas tectores e glandulares pedicelados bem distribuídos, antrorsos ou retrorsos; limbo da corola 10-13 mm diâm.

16. Cálice com tricomas tectores e glandulares pedicelados, retrorsos; lacínias triangular-lanceoladas.......

5. G. guaranitica

16. Cálice com tricomas tectores e glandulares subsésseis, antrorsos; lacínias mucronadas ..... 12. G. megapotamica

15. Cálice com tricomas tectores e glandulares pedicelados sobre as costelas, em várias

direções, a maioria patentes; limbo da corola 17-22 mm diâm.

15.G. phlogiflora

10. Corola externamente glabra ou com tricomas não glandulares

17. Corola externamente glabra

18. Pedúnculo da florescência glabro a subglabro, com pouquíssimos tricomas tectores antrorsos; par superior de estames com apêndices conectivais que não superam as tecas ou da mesma altura, inclusos; cálice 6-7 mm compr.; tubo da corola 9-11 mm compr.; limbo 4,5 mm diâm.

7. G. herteri

18. Pedúnculo da florescência hirto, com tricomas tectores patentes e retrorsos, e tricomas glandulares; par superior de estames com apêndices conectivais que superam as tecas, exsertos; cálice 9-10 mm compr.; tubo da corola 12-15 mm compr.; limbo 8-9 mm diâm.

19. G. scrobiculata

17. Corola externamente pilosa

19. Par superior de estames com apêndices conectivais que superam as tecas, exsertos

17. G. pulchra

19. Par superior de estames com apêndices conectivais que não superam as tecas, inclusos, ou sem apêndices

20. Folhas sésseis, brevemente decurrentes no caule

21. Brácteas florais 4-9 mm compr.; lacínias do cálice 0,2-0,7 mm compr., triangular-lanceoladas; corola 12-13 mm compr., e limbo $10 \mathrm{~mm}$ diâm.; folhas com superfície adaxial estrigosa........21. G. sessilis

21. Brácteas florais 12-15 mm compr.; lacínias do cálice 1,3-2,5 mm compr., lanceoladas; corola 14-15 mm compr., limbo 7-8 mm diâm.; folhas com superfície adaxial glabra.... 22. G. stellarioides

20. Folhas pecioladas, lâminas decurrentes no pecíolo

22. Par superior de estames sem apêndices conectivais

23. Corola lilás a roxa; folhas trilobadas

8. G. humifusa

23. Corola vermelha; folhas inteiras

14. G. peruviana

22. Par superior de estames com apêndices conectivais vestigiais ou desenvolvidos

24. Tubo da corola 5-9 mm compr. e limbo 3,5-7 $\mathrm{mm}$ diâm.

25. Brácteas florais 4-7 mm compr.; cálice 6-8 mm compr.; corola 7-9 mm compr.; com apêndices conectivais vestigiais; estilete $6-8 \mathrm{~mm}$ compr.

3. G. corymbosa

25. Brácteas florais 2-3,5 mm compr.; cálice 4-6 mm compr.; corola 5-6 mm compr.; com apêndices conectivais desenvolvidos, inclusos; estilete $4 \mathrm{~mm}$ compr.

10. G. lobata

24. Tubo da corola 13-18 mm compr. e limbo 7-17 mm diâm.

26. Pedúnculo hirto a híspido, com tricomas tectores em várias direções e tricomas glandulares; lacínias do cálice 1,5-2 mm compr., lanceoladas; limbo da corola 14-17 mm compr.; estilete 12-15 mm compr.

11. G. marrubioides

26. Pedúnculo hirsuto, com tricomas tectores e glandulares retrorsos; lacínias do cálice 0,1-1 mm compr., triangulares a mucronadas; limbo da corola $7 \mathrm{~mm}$ compr.; estilete 9-10 mm compr. 
1. Glandularia aristigera (S. Moore) Tronc., Darwiniana 14(4): 636. 1968.

Fig. 1-9

Ervas rasteiras, radicantes nos nós, com $12-50 \mathrm{~cm}$ compr. Caule piloso, com tricomas tectores adpressos e antrorsos; entrenós $0,5-4,5 \mathrm{~cm}$ compr. Folhas pinatissectas, com 3 a 5 lobos divididos em 2 ou mais segmentos lineares; lâmina 1,5-4x0,9-3 cm, decurrente no pecíolo; face adaxial estrigosa, com tricomas tectores adpressos, face abaxial estrigosa, com tricomas tectores adpressos e glandulares subsésseis; pecíolo 4-9 mm compr. Inflorescências em monobótrios ou pleiobótrios heterotéticos com 1 par de paracládios simples; florescências 1,5-2,5x1,5-2,7 cm, em espigas multifloras, umbeliformes na antese, com raque alongada na frutificação até $8 \mathrm{~cm}$ compr.; pedúnculo das florescências piloso, com tricomas tectores adpressos, antrorsos. Brácteas 3-5 mm compr., lanceoladas, pubescentes, com tricomas tectores e glandulares subsésseis, margem ciliada, com menos tricomas em direção ao ápice. Cálice 8-10 mm compr., pubescente, com tricomas tectores adpressos e antrorsos, e glandulares subsésseis, bem distribuídos; lacínias 1-2 mm compr., lanceoladas a subuladas, coniventes ou contortas no fruto. Corola hipocrateriforme, lilás, externamente glabra, tubo 11-14 mm compr., limbo 7-10 mm diâm. Par superior de estames com apêndices conectivais que não superam as tecas, inclusos. Estilete 10-12 mm compr.; ovário ca. $1 \mathrm{~mm}$ compr. Clusas 2,8-5 mm compr., ápice agudo ou obtuso, base alargada ou não alargada, face ventral papilosa, face dorsal reticulada na porção superior e estriada na inferior.

Ocorre no Brasil, Bolívia, Paraguai, Argentina e Uruguai (Múlgura 2007). No Rio Grande do Sul é encontrada principalmente no Planalto Médio, Campanha, Missões e Alto Uruguai, nos campos, terrenos arenosos e beiras de estrada. Espécie muito semelhante a $G$. tenera, da qual difere principalmente por possuir apêndices conectivais que superam as tecas, exsertos. Floresce e frutifica de agosto a março.

Material examinado selecionado: BRASIL. Rio Grande do Sul: Cruz Alta, 3/X/2007, fl., V. Thode 70 (ICN); São Borja, 7/VIII/2007, fl. fr., V. Thode 188 (ICN); Tenente Portela, 21/VII/1981, fl., M. Sobral et al. 242 (ICN); Uruguaiana, $7 /$ XII/2007, fl. fr., V. Thode 207 (ICN).

2. Glandularia catharinae (Moldenke) O'Leary \& P. Peralta, Darwiniana 45(2): 219. 2007.

Fig. 10-18

Ervas rasteiras, radicantes nos nós, com 10-80 cm compr. Caule hirto, com tricomas tectores e glandulares pedicelados em várias direções, a maioria patentes; entrenós $0,4-2,7 \mathrm{~cm}$ compr. Folhas pinatissectas, com 3 lobos divididos em 2 ou mais segmentos linear-obovados; lâmina 0,6-1,5x0,5-1,7 $\mathrm{cm}$, decurrente no pecíolo; face adaxial glabra a hirta, com tricomas tectores, face abaxial hirta, com tricomas tectores patentes e glandulares pedicelados mais curtos, principalmente sobre as nervuras; pecíolo 2-7 mm compr. Inflores- cências em monobótrios ou pleiobótrios heterotéticos com 1 par de paracládios simples; florescências 1-2,5x1,5-3,3 cm, em espigas multifloras, umbeliformes na antese, com raque alongada na frutificação até $2,5 \mathrm{~cm}$; pedúnculo das florescências hirto, com tricomas tectores e glandulares pedicelados em várias direções, a maioria patentes. Brácteas 2-4,1 $\mathrm{mm}$ compr., oval-lanceoladas, subglabras, com tricomas tectores e glandulares pedicelados, margem ciliada. Cálice 7-8 mm compr., hirto, com tricomas tectores e glandulares pedicelados em várias direções, a maioria patentes; lacínias 0,3-1 mm compr., triangulares, coniventes no fruto. Corola hipocrateriforme, lilás, externamente pilosa, tubo $12-15 \mathrm{~mm}$ compr., limbo 9-12 mm diâm. Par superior de estames com apêndices conectivais que não superam as tecas, inclusos. Estilete 9-11 mm compr.; ovário ca. $1 \mathrm{~mm}$ compr. Clusas 2,5-4 mm compr., ápice obtuso, base alargada ou não, face ventral papilosa, face dorsal reticulada na porção superior e estriada na inferior.Ocorre no Brasil, nos estados do Paraná, Santa Catarina e Rio Grande do Sul, onde é encontrada principalmente nos Campos de Cima da Serra, formando grandes populações. Cresce em campos pedregosos, sobre rochas, barrancos, campos úmidos, turfeiras e beiras de estrada. Difere de G. aristigera, G. selloi e G. tenera, principalmente, por seus longos tricomas tectores patentes, sempre presentes na face abaxial das folhas. Difere de G. jordanensis por possuir flores muito maiores e florescências mais vistosas. Floresce e frutifica de setembro a março.

Material examinado selecionado: BRASIL. Rio Grande do Sul: Caxias do Sul, 22/X/2005, fl., F. Marchett 402 (HUCS); São Francisco de Paula, 14/IX/2007, fl., V. Thode 15 (ICN); São Sebastião do Caí, 10/XI/1940, fl., B. Rambo 6624.

3. Glandularia corymbosa (Ruiz \& Pav.) O'Leary \& P. Peralta, Darwiniana 45(2): 219. 2007.

Fig. 19-27

Ervas ou subarbustos eretos, com 0,3-1 m alt. Caule subglabro a hirto, com tricomas tectores e glandulares pedicelados em várias direções, sendo a maioria patentes; entrenós 3,4-10,6 cm compr. Folhas inteiras; lâmina 1,86,9x1-3,2 cm, oval-lanceolada a oblonga, ápice agudo, base obtusa a truncada, decurrente no pecíolo, margem serreadodentada; face adaxial hirta a estrigosa, face abaxial subglabra a estrigosa, com tricomas sobre as nervuras; pecíolo 1-6 mm compr. Inflorescências em monobótrios ou pleiobótrios heterotéticos com 2 ou 3 pares de paracládios simples ou trímeros; florescências 1,1-1,3x1,5-2 cm, em espigas multifloras, umbeliformes a cilíndricas na antese, com raque alongada na frutificação até $4 \mathrm{~cm}$; pedúnculo das florescências hirto, com tricomas tectores e glandulares pedicelados em várias direções. Brácteas 4-7 mm compr., lanceoladas, hirtas, com poucos tricomas tectores e glandulares pedicelados, margem ciliada. Cálice 6-8 mm compr., hirto a híspido, com tricomas tectores antrorsos e tricomas glandulares pedicelados; lací- 


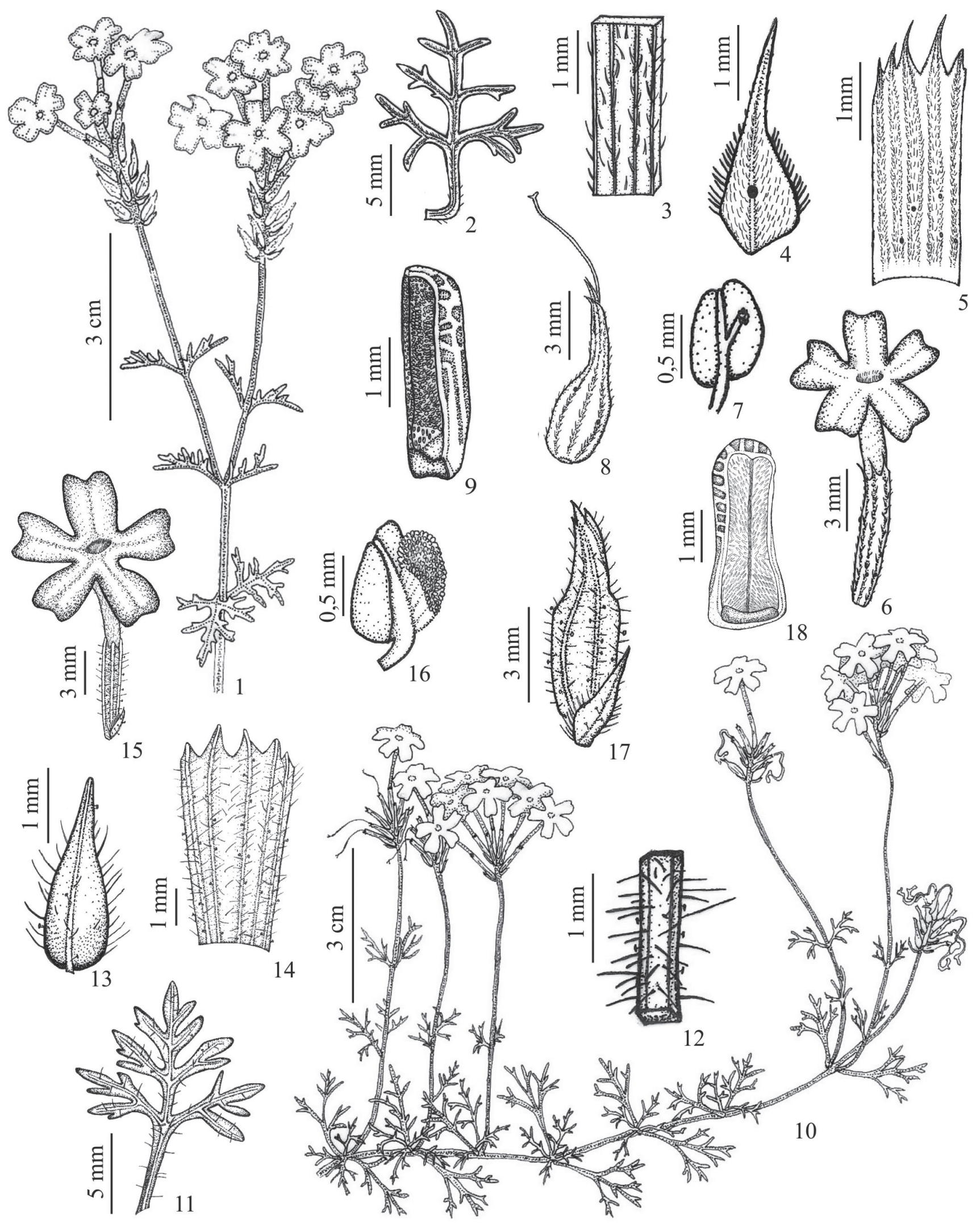

Figuras 1-9. Glandularia aristigera (S. Moore) Tronc. 1. Ramo (V. Thode 70). 2. Folha, face abaxial. 3. Indumento do pedúnculo das florescências. 4. Bráctea. 5. Cálice aberto. 6. Flor. 7. Antera do par superior de estames com apêndice no conectivo, vista dorsal. 8. Cálice frutífero com estilete. 9. Clusa, vista lateral ( $V$. Thode 188). Figuras 10-18. Glandularia catharinae (Moldenke) O'Leary \& P. Peralta. 10. Ramo (F. Marchett 402). 11. Folha, face abaxial. 12. Indumento do pedúnculo das florescências. 13. Bráctea. 14. Cálice aberto. 15. Flor. 16. Antera do par superior de estames com apêndice no conectivo, vista dorsal. 17. Cálice frutífero. 18. Clusa, vista ventral (V. Thode 15). 
nias $0,2-0,7 \mathrm{~mm}$ compr., triangular-lanceoladas, coniventes no fruto. Corola infundibuliforme, lilás, externamente pilosa, tubo 7-9 mm compr., limbo ca. 3,5 mm diâm. Par superior de estames com apêndices conectivais vestigiais. Estilete 6-8 mm compr.; ovário ca. $1 \mathrm{~mm}$ compr. Clusas $2,5 \mathrm{~mm}$ compr., ápice obtuso, base alargada ou não, face ventral papilosa, face dorsal reticulada no terço superior e estriada no restante.

Ocorre no Brasil, Uruguai e Chile (O'Leary \& Peralta 2007). No Estado ocorre principalmente nos Campos de Cima da Serra, onde é encontrada em campos, turfeiras, banhados e bordas de mata. Apresenta um tipo de inflorescência com pleiobótrios heterotéticos com 2 ou 3 pares de paracládios trímeros, que difere da maioria das espécies do gênero. Floresce e frutifica de setembro a fevereiro.

Material examinado selecionado: BRASIL. Rio Grande do Sul: Caxias do Sul, 27/XI/1998, fl., A. Knob 5790 (UNILASALLE); Gramado, 28/XII/1949, fl. fr., A. Sehnem 4155 (HUCS, PACA); Lavras do Sul, 2004, fl. fr., S. Bordignon et al. 3077 (HERULBRA); São José dos Ausentes, 19/XI/2007, fl., $V$. Thode 156 (ICN).

\section{Glandularia guaibensis P. Peralta \& Thode, Rodriguéisia} 61(1): S30. 2010.

Fig. 28-35

Ervas eretas a prostradas, com 0,5-1 m alt. Caule hirsuto, com tricomas tectores em várias direções, sendo a maioria retrorsos, e tricomas glandulares pedicelados; entrenós 2-8 cm compr. Folhas inteiras; lâmina 2,5-7x0,6-1,8 cm, elíptica a ovalada, ápice agudo, base atenuada, lâmina decurrente no pecíolo, margem inteira no terço inferior e serreada nos dois terços superiores; face adaxial estrigosa, com tricomas tectores bem distribuídos, face abaxial híspida, com tricomas tectores principalmente sobre as nervuras; pecíolo 2-3 $\mathrm{mm}$ compr. Inflorescências em monobótrios ou pleiobótrios, com 1 a 2 pares de paracládios simples; florescências 1,3-2,5x1,5$2,5 \mathrm{~cm}$ em espigas multifloras, umbeliformes na antese, com raque alongada na frutificação até $6 \mathrm{~cm}$; pedúnculo das florescências hirsuto, com tricomas tectores e glandulares pedicelados retrorsos. Brácteas 6-7 $\mathrm{mm}$ compr., lanceoladas, pilosas, com tricomas tectores e glandulares pedicelados bem distribuídos, margem ciliada. Cálice $8-9$ mm compr., hirsuto, com tricomas tectores maiores em várias direções, mais evidentes sobre as costelas, e menores retrorsos e glandulares pedicelados; lacínias 0,1-1 mm compr., triangulares a mucronadas, coniventes no fruto. Corola hipocrateriforme, de róseo-clara a lilás, externamente pilosa, tubo 13-14 mm compr., limbo $7 \mathrm{~mm}$ diâm. Par superior de estames com apêndices conectivais que não superam as tecas, inclusos. Estilete 9-10 mm compr.; ovário ca. $1 \mathrm{~mm}$ compr. Clusas 3-4 mm compr., ápice obtuso, base não alargada, face ventral lisa, face dorsal reticulada.

Todos os exemplares examinados foram coletados no Rio Grande do Sul, município de Guaíba (Depressão Central), em banhado. Floresce e frutifica de outubro a janeiro.
Material examinado selecionado: BRASIL. Rio Grande do Sul: Guaíba, 6/X/1985, fl. fr., N.I. Matzenbacher s.n. (ICN 63933); idem, 31/I/1988, fl. fr, S.A. Bordignon et al. s.n. (ICN 68622, SI); idem, X/1992, fl., M. Sobral \& S. Bordignon 7396 (ICN); idem, 28/IX/2007, fl. fr., V. Thode 31 (ICN).

\section{Glandularia guaranitica Tronc., Darwiniana 16(3-4):} 618. 1971.

Fig. 36-42

Ervas ou subarbustos eretos, com 0,5-1,2 m alt. Caule hirto a híspido, com tricomas tectores e glandulares pedicelados retrorsos; entrenós 1,3-7 cm compr. Folhas inteiras, lâmina 1,4-5,7x0,6-2 cm, oval-lanceolada, ápice agudo, base brevemente atenuada a subtruncada, decurrente no pecíolo, margem serreada, face adaxial estrigosa, face abaxial estrigosa, com tricomas mais longos sobre as nervuras; pecíolo 1-6 mm compr. Inflorescências em monobótrios ou pleiobótrios heterotéticos com 1 a 5 pares de paracládios simples; florescências 1,7-2×3-4,3 $\mathrm{cm}$, em espigas multifloras, umbeliformes na antese, com raque não alongada na frutificação; pedúnculo das florescências hirto a híspido, com tricomas tectores e glandulares pedicelados retrorsos. Brácteas 2,1-6 mm compr., oval-lanceoladas, com tricomas tectores e glandulares pedicelados, margem ciliada. Cálice 11-15 mm compr., hirto a híspido, com tricomas tectores e glandulares pedicelados bem distribuídos, retrorsos; lacínias 0,9-1,8 mm compr., triangular-lanceoladas, coniventes no fruto. Corola hipocrateriforme, lilás, com tricomas glandulares externamente, tubo 12-22 $\mathrm{mm}$ compr., limbo 10-12 mm diâm. Par superior de estames com apêndices conectivais que não superam as tecas, inclusos. Estilete 12-19 mm compr.; ovário ca. $1 \mathrm{~mm}$ compr. Clusas 5-6 mm compr., ápice brevemente agudo projetado para a frente, base alargada ou não, face ventral lisa ou papilosa, face dorsal reticulada na metade superior e estriada na inferior.

Ocorre no Paraguai e Argentina, nas Províncias de Misiones e Corrientes (Troncoso 1971), sendo esta a primeira citação para o Rio Grande do Sul, onde é encontrada principalmente nas Missões e Alto Uruguai. Habita campos, bordas de mata e beiras de estrada. Esta espécie apresenta semelhanças com G. megapotamica e G. phlogiflora, como o hábito, presença de apêndices conectivais inclusos no par superior de estames, corola com tricomas glandulares externamente, florescências com tricomas retrorsos no pedúnculo e raque não alongada na frutificação. As três espécies diferem principalmente pelo indumento do cálice, já que $G$. guaranitica possui tricomas bem distribuídos e retrorsos, $G$. megapotamica também apresenta tricomas bem distribuídos, porém antrorsos e G. phlogiflora possui tricomas sobre as costelas, em várias direções, a maioria patentes. Esta última apresenta o limbo da corola maior $(17-22 \mathrm{~mm})$ que os das outras duas espécies (10-13 mm). Floresce e frutifica de outubro a fevereiro. 


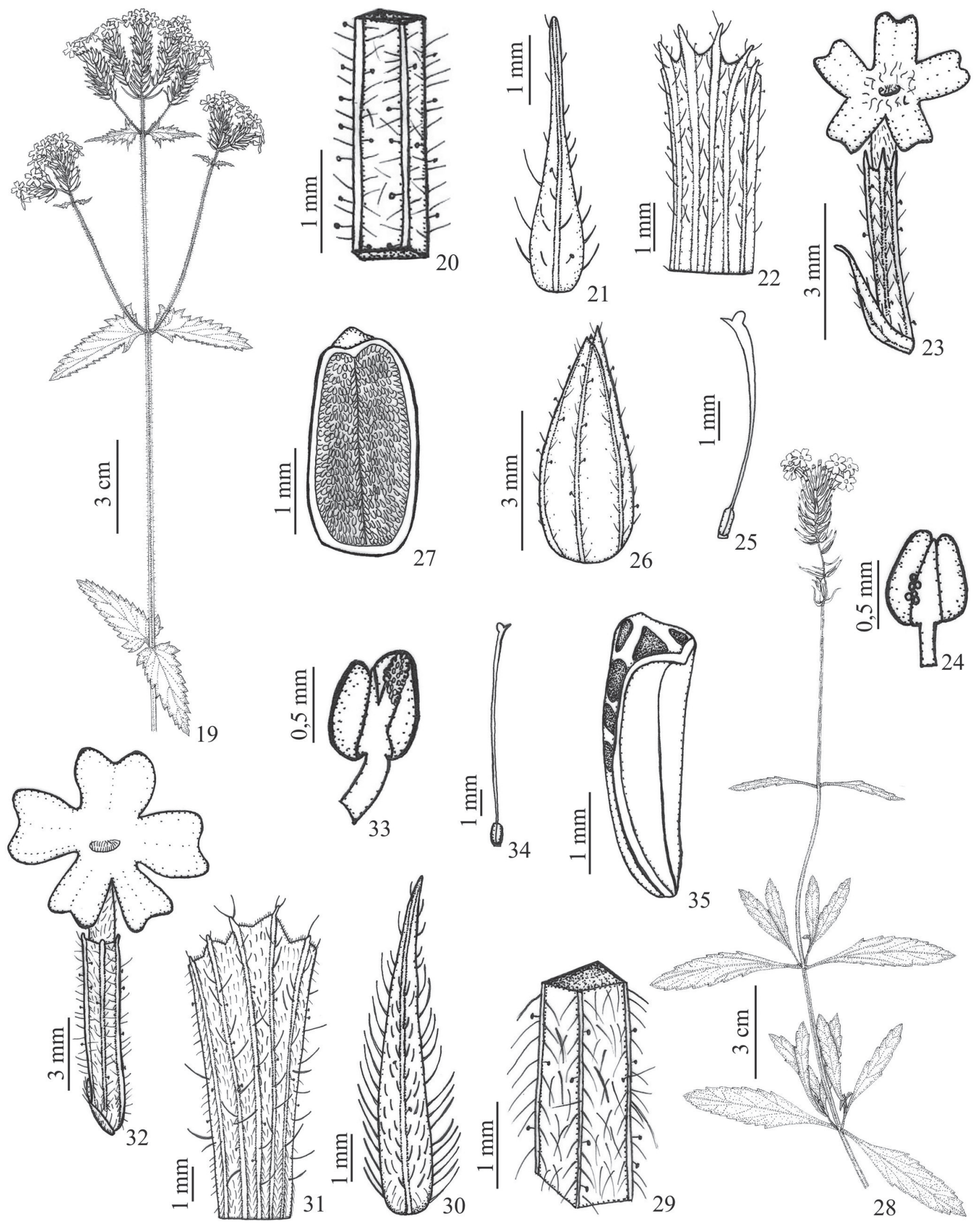

Figuras 19-27. Glandularia corymbosa (Ruiz \& Pav.) O'Leary \& P. Peralta. 19. Ramo (M. Sobral et al. 8093). 20. Indumento do pedúnculo das florescências. 21. Bráctea. 22. Cálice aberto. 23. Flor. 24. Antera do par superior de estames com apêndice vestigial no conectivo, vista dorsal. 25. Gineceu. 26. Cálice frutífero. 27. Clusa, vista ventral (S. Bordignon 3077). Figuras 28-35. Glandularia guaibensis P. Peralta \& Thode. 28. Ramo (V. Thode 31). 29. Indumento do pedúnculo das florescências. 30. Bráctea. 31. Cálice aberto. 32. Flor. 33. Antera do par superior de estames com apêndice no conectivo, vista dorsal. 34. Gineceu. 35. Clusa, vista lateral (N.I. Matzenbacher s.n., ICN 63933). 
Material examinado selecionado: BRASIL. Rio Grande do Sul: Chiapeta, 12/X/1985, fl. fr., E.T.H. Franco s.n. (ICN 64366); Erebango, 14/XI/1995, fl., A. Butzke s.n. (HUCS 11274); Panambi, 14/I/1970, fl., A. Sehnem s.n. (PACA 87459).

\section{Glandularia hasslerana (Briq.) Tronc., Darwiniana 19(2-} 4): 738.1975.

Fig. 43-50

Ervas ou subarbustos eretos a prostrados, com 0,3 a mais de $1 \mathrm{~m}$ alt. Caule estrigoso a pubescente, com tricomas tectores retrorsos e poucos tricomas glandulares pedicelados; entrenós 4,4-11 cm compr. Folhas inteiras; lâmina 2,8-11x1$3,9 \mathrm{~cm}$, oval-lanceolada, ápice agudo, base brevemente atenuada a aguda, decurrente no pecíolo, margem serreada; face adaxial estrigosa, face abaxial estrigosa, com tricomas mais evidentes sobre as nervuras; pecíolo 0,5-2 cm compr. Inflorescências em monobótrios ou pleiobótrios heterotéticos com 1 par de paracládios simples; florescências 2-3x1,8-3,5 $\mathrm{cm}$, em espigas multifloras, umbeliformes na antese, com raque alongada na frutificação até $5 \mathrm{~cm}$; pedúnculo das florescências estrigoso a pubescente, com tricomas tectores retrorsos e poucos tricomas glandulares pedicelados. Brácteas 8-12 mm compr., linear-lanceoladas, pubescentes, com tricomas tectores bem distribuídos, margem ciliada. Cálice 12-15 mm compr., pubescente, com tricomas tectores em várias direções, a maioria patentes e retrorsos, mais evidentes sobre as costelas, e tricomas glandulares pedicelados; lacínias 1,8-4 mm compr., lanceoladas, coniventes no fruto. Corola hipocrateriforme, rosa a lilás, com tricomas glandulares externamente, tubo 19-20 mm compr., limbo 9-15 mm diâm. Par superior de estames sem apêndices conectivais. Estilete 15-17 mm compr.; ovário ca. $1 \mathrm{~mm}$ compr. Clusas $4 \mathrm{~mm}$ compr., ápice obtuso projetado para a frente, base alargada, face ventral papilosa, face dorsal reticulada na porção superior e estriada na inferior.

Ocorre no Paraguai e na Argentina, nas Províncias de Corrientes e Misiones (Múlgura 2007), sendo esta a primeira citação para o Estado, onde é encontrada predominantemente na Campanha, em campos úmidos e banhados. Glandularia hasslerana apresenta semelhanças com G. megapotamica e G. phlogiflora, sendo distinta destas principalmente por suas brácteas linear-lanceoladas e maiores e por suas florescências alongadas na frutificação. Floresce e frutifica de dezembro a março.

Material examinado selecionado: BRASIL. Rio Grande do Sul: Alegrete, 11/III/2003, fl., A. Knob \& S. Bordignon 7415 (UNILASALLE); Tupanciretã, 26/I/1942, fl., B. Rambo 9388 (PACA).

7. Glandularia herteri (Moldenke) Tronc., Darwiniana 19(2-4): 738. 1975.

Fig. 51-58

Ervas prostradas, com 10-19 cm compr. Caule subglabro a glabro, com poucos tricomas tectores antrorsos; entrenós
1-2,5 cm compr. Folhas inteiras, lâmina $0,8-1,6 \times 0,7-1,1 \mathrm{~cm}$, ovalada, ápice obtuso a cuneado, base atenuada a cuneada, decurrente no pecíolo, margem lisa na metade inferior e lobada na metade superior; face adaxial e face abaxial glabras; pecíolo 2-9 mm compr. Inflorescências em monobótrios; florescências $1,5 \times 1,7 \mathrm{~cm}$, em espigas multifloras, umbeliformes na antese, com raque alongada na frutificação até 2 $\mathrm{cm}$; pedúnculo das florescências glabro a subglabro, com pouquíssimos tricomas tectores antrorsos. Brácteas 3,5-4 mm compr., lanceoladas, subglabras, com tricomas tectores, margem ciliada com poucos tricomas. Cálice 6-7 mm compr., piloso, com poucos tricomas tectores e glandulares pedicelados antrorsos; lacínias 0,5-1 mm compr., triangularlanceoladas, coniventes no início da frutificação. Corola hipocrateriforme, lilás, externamente glabra, tubo 9-11 mm compr., limbo 4,5 mm diâm. Par superior de estames com apêndices conectivais que não superam as tecas, inclusos. Estilete 7-8 mm compr.; ovário ca. $0,9 \mathrm{~mm}$ compr. Clusas não vistas.

Espécie pouco comum, sendo também encontrada no Uruguai, no Departamento de Artigas. No Rio Grande do Sul ocorre na Campanha, nos campos de gramíneas, em solos úmidos. Difere das demais espécies do gênero por possuir folhas ovaladas, com pecíolo longo e por ser subglabra. Floresce e frutifica de novembro a janeiro.

Material examinado: BRASIL. Rio Grande do Sul: Quaraí, 3/I/1945, fl., B. Rambo 26125 (PACA); idem, 08/ VIII/2008, estér., I. Boldrini 1513 (ICN); Uruguaiana, 27/ XI/1979, fl., T.M. Pedersen 12554 (MBM, SI, NY).

8. Glandularia humifusa (Cham.) Botta, Hickenia 2(28): 128. 1995.

Fig. 59-67

Ervas rasteiras, com $11-50 \mathrm{~cm}$ compr. Caule hirto a híspido, com tricomas tectores longos, em várias direções e tricomas glandulares pedicelados, e com poucos tricomas tectores curtos, retrorsos ou patentes, ou estes ausentes; entrenós $0,5-5,7 \mathrm{~cm}$. Folhas trilobadas, com os lobos divididos; lâmina 0,9-3,3 x0,9-2,8 cm, ovalada a oval-lanceolada, ápice cuneado a obtuso, base aguda a cuneada, decurrente no pecíolo, margem inteira; face adaxial estrigosa, face abaxial pilosa a híspida, com tricomas mais evidentes sobre as nervuras, com ou sem tricomas glandulares pedicelados; pecíolo 1-5 mm compr. Inflorescências em monobótrios ou pleiobótrios heterotéticos com 1 par de paracládios simples; florescências 1,8-3x2-4 cm, em espigas multifloras, umbeliformes na antese, com raque alongada na frutificação até 5 $\mathrm{cm}$; pedúnculo das florescências hirto a híspido, com tricomas tectores e glandulares pedicelados em várias direções. Brácteas 3-5 mm compr., lanceoladas, pilosas, com tricomas tectores e glandulares pedicelados, margem ciliada. Cálice 8-10 mm compr., hirto a híspido, com tricomas tectores mais evidentes sobre as costelas, antrorsos e tricomas glandulares pedicelados; lacínias $0,3-0,8 \mathrm{~mm}$ compr., triangular-lance- 


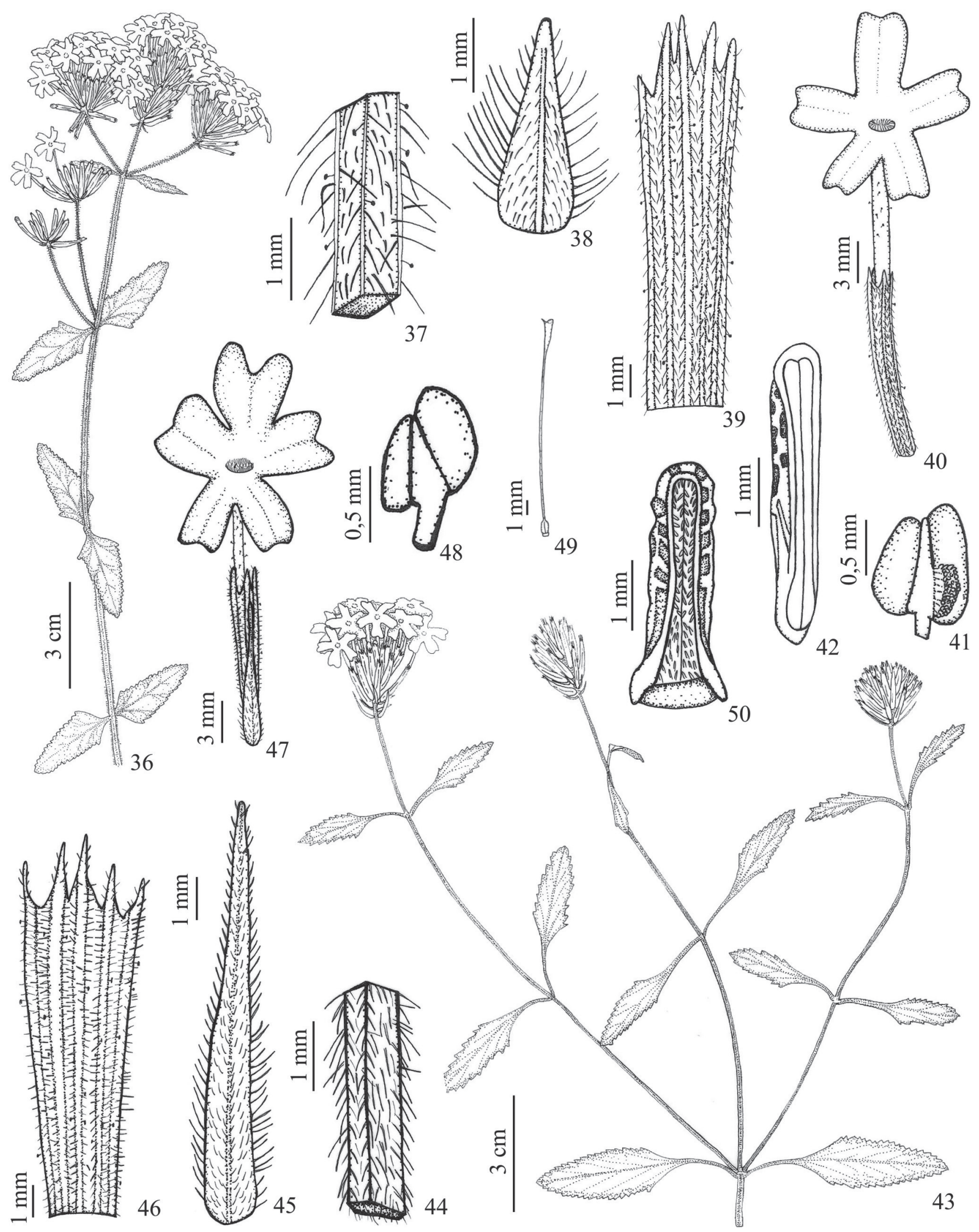

Figuras 36-42. Glandularia guaranitica Tronc. 36. Ramo. 37. Indumento do pedúnculo das florescências. 38. Bráctea. 39. Cálice aberto. 40. Flor. 41. Antera do par superior de estames com apêndice no conectivo, vista dorsal. 42. Clusa, vista ventral (E.T.H. Franco s.n., HUCS 11274). Figuras 43-50. Glandularia hasslerana (Briq.) Tronc. 43. Ramo (A. Knob \& S. Bordignon 6690). 44. Indumento do pedúnculo das florescências. 45. Bráctea. 46. Cálice aberto. 47. Flor. 48. Antera do par superior de estames, vista dorsal. 49. Gineceu. 50. Clusa, vista ventral (M. Sobral et al. 7697) 


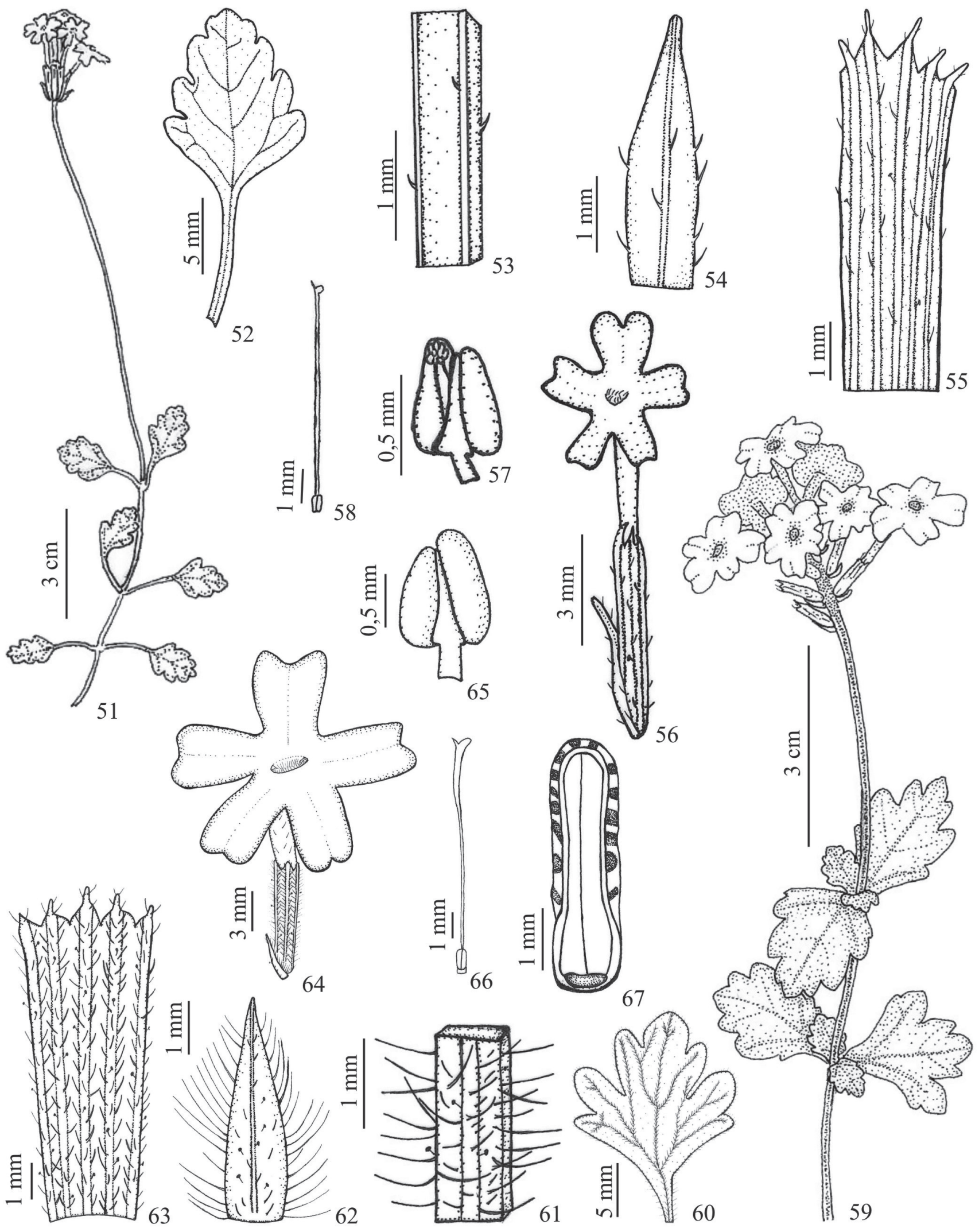

Figuras 51-58. Glandularia herteri (Moldenke) Tronc. 51. Ramo (T.M. Pedersen 12554). 52. Folha, face abaxial. 53. Indumento do pedúnculo das florescências. 54. Bráctea. 55. Cálice aberto. 56. Flor. 57. Antera do par superior de estames com apêndice no conectivo, vista dorsal. 58. Gineceu (B. Rambo 26125). Figuras 59-67. Glandularia humifusa (Cham.) Botta. 59. Ramo. 60. Folha, face abaxial. 61. Indumento do pedúnculo das florescências. 62. Bráctea. 63. Cálice aberto. 64. Flor. 65. Antera do par superior de estames, vista dorsal. 66. Gineceu. 67. Clusa, vista ventral (V. Thode 99). 
oladas, coniventes no fruto. Corola hipocrateriforme, lilás a roxa, externamente pilosa, tubo 11-15 mm compr., limbo 14-18 mm diâm. Par superior de estames sem apêndices conectivais. Estilete 10-12 mm compr.; ovário ca. $1 \mathrm{~mm}$ de compr. Clusas 4-5 mm compr., ápice obtuso, base alargada ou não, face ventral lisa a papilosa, face dorsal reticulada na porção superior e estriada na inferior.

Foi encontrada, até o momento, apenas no Brasil, no Rio Grande do Sul, principalmente na Depressão Central. Cresce em campos, barrancos em beiras de estrada, campos pedregosos e solos arenosos. Glandularia humifusa pode ser confundida com G. marrubioides, da qual difere, entre outras características, por apresentar folhas trilobadas com nervuras menos evidentes na face abaxial e cálice com lacínias menores. Floresce e frutifica de setembro a novembro.

Material examinado selecionado: BRASIL. Rio Grande do Sul: Amaral Ferrador, 8/X/1977, fl., M. Fleig 753 (ICN); Osório, 2/X/1950, fl., B. Rambo 48911 (PACA); Porto Alegre, 25/IX/1995, fl., R.S. Rodrigues 195 (ICN); São Leopoldo, 3/IX/1949, fl., B. Rambo 43261 (PACA).

\section{Glandularia jordanensis (Moldenke) O'Leary \& P. Pe-} ralta, Darwiniana 45(2): 228. 2007.

Fig. 68-77

Ervas prostradas, com 12-19 cm compr. Caule hirto, com tricomas tectores e glandulares pedicelados em várias direções, a maioria patentes; entrenós 0,5-2,3 cm compr. Folhas pinatissectas a pinatipartidas, 3 lobos divididos ou não em 2 ou mais segmentos obovados; lâmina 0,5 1x0,5-1,1 cm, oval-lanceolada, ápice agudo, base breve atenuada, decurrente no pecíolo; face adaxial estrigosa, face abaxial com tricomas principalmente sobre as nervuras; pecíolo até $1 \mathrm{~mm}$ compr. Inflorescências em monobótrios ou pleiobótrios heterotéticos com 1 par de paracládios simples; florescências $0,5 \times 0,8 \mathrm{~cm}$, em espigas paucifloras, umbeliformes na antese, com raque alongada na frutificação até $1,5 \mathrm{~cm}$; pedúnculo das florescências hirto, com tricomas tectores e glandulares pedicelados em várias direções, a maioria patentes. Brácteas 2,9-3,5 mm compr., lanceoladas, subglabras, com poucos tricomas tectores e glandulares pedicelados, margem ciliada. Cálice 4-4,5 mm compr., hirto, com tricomas tectores antrorsos e tricomas glandulares pedicelados, principalmente sobre as costelas; lacínias 0,2-0,5 mm compr., triangulares, coniventes no fruto. Corola hipocrateriforme, branca a lilás, externamente glabra, tubo 4-5 mm compr., limbo 2 mm diâm. Par superior de estames com apêndices conectivais que não superam as tecas, inclusos. Estilete 3-4 mm compr.; ovário ca. 0,5 mm compr. Clusas 2,5 mm compr., ápice obtuso, base não alargada, face ventral papilosa, face dorsal reticulada na porção superior e estriada na inferior.

Ocorre no Brasil, nos estados do Paraná, Santa Catarina e Rio Grande do Sul, onde cresce nos Campos de Cima da
Serra. Prefere campos secos. Ver comentários em G. catharinae. Floresce e frutifica de dezembro a março.

Material examinado selecionado: BRASIL. Rio Grande do Sul: Bom Jesus, 15/I/1942, fl. fr., B. Rambo 8777 (PACA); Cambará do Sul, XII/1983, fl. fr., M. Sobral \& J.R. Stehmann 2742 (ICN); São Francisco de Paula, 28/III/2001, fr., A. Knob \& S. Bordignon 6740 (UNILASSALE).

10. Glandularia lobata (Vell.) P. Peralta \& Thode, Rodriguésia 61(1): S30. , 2010.

Fig. 78-87

Ervas eretas a prostradas, com 0,2-1 m alt. Caule pubescente a hirto, com tricomas tectores e glandulares pedicelados em várias direções; entrenós 1,7-8 cm compr. Folhas inteiras; lâmina 1,4-6x0,8-3 cm, ovalada a oval-lanceolada, ápice agudo, base obtusa a subtruncada, decurrente no pecíolo, margem serreada a inciso-serreada; face adaxial estrigosa a hirta, com tricomas tectores bem distribuídos, face abaxial pubescente, estrigosa ou hirta, com tricomas tectores bem distribuídos ou mais evidentes sobre as nervuras; pecíolo 0,4-1,5 cm compr. Inflorescências em pleiobótrios heterotéticos com 2 a 5 pares de paracládios simples a tetrâmeros; florescências 0,9-1,6x1,3-2 cm, em espigas multifloras ou paucifloras, cilíndricas na antese, com raque alongada até 3 $\mathrm{cm}$ na frutificação; pedúnculo das florescências pubescente a hirto, com tricomas tectores e glandulares pedicelados em várias direções. Brácteas 2-3,5 mm compr., oval-lanceoladas, subglabras a pilosas, com tricomas tectores e glandulares pedicelados principalmente sobre a nervura central, margem ciliada. Cálice 4-6 mm compr., híspido a piloso, com tricomas tectores e glandulares pedicelados principalmente sobre as costelas, antrorsos e patentes; lacínias 0,8-1,5 mm compr., triangular-lanceoladas, coniventes no fruto. Corola hipocrateriforme, lilás a roxa, externamente pilosa, tubo 5-6 mm compr., limbo 6-7 mm diâm. Par superior de estames com apêndices conectivais que superam ou não as tecas, inclusos. Estilete $4 \mathrm{~mm}$ compr.; ovário ca. $1 \mathrm{~mm}$ compr. Clusas 2-2,5 mm compr., ápice obtuso, base não alargada, face ventral papilosa, face dorsal reticulada no terço superior e estriada no restante.

Ocorre nas regiões leste do Paraguai, nordeste da Argentina e no Brasil. No Rio Grande do Sul, foi encontrada principalmente nos Campos de Cima da Serra, e mais raramente em outras regiões, em campos, bordas de mata, terrenos úmidos e pedregosos. As inflorescências possuem um padrão diferente das demais espécies do gênero e muitas vezes apresentam quatro florescências partindo de um mesmo nó. Floresce e frutifica de outubro a março.

Material examinado selecionado: BRASIL. Rio Grande do Sul: Cambará do Sul, 18/XI/2007, fl. fr., V. Thode 147 (ICN); Caxias do Sul, 24/II/1954, fl. fr., B. Rambo 55076 (PACA); Montenegro, 21/XII/1934, fl., B. Rambo 2293 (PACA); Palmeira das Missões, 30/I/1954, fl., B. Rambo 51949 (PACA). 


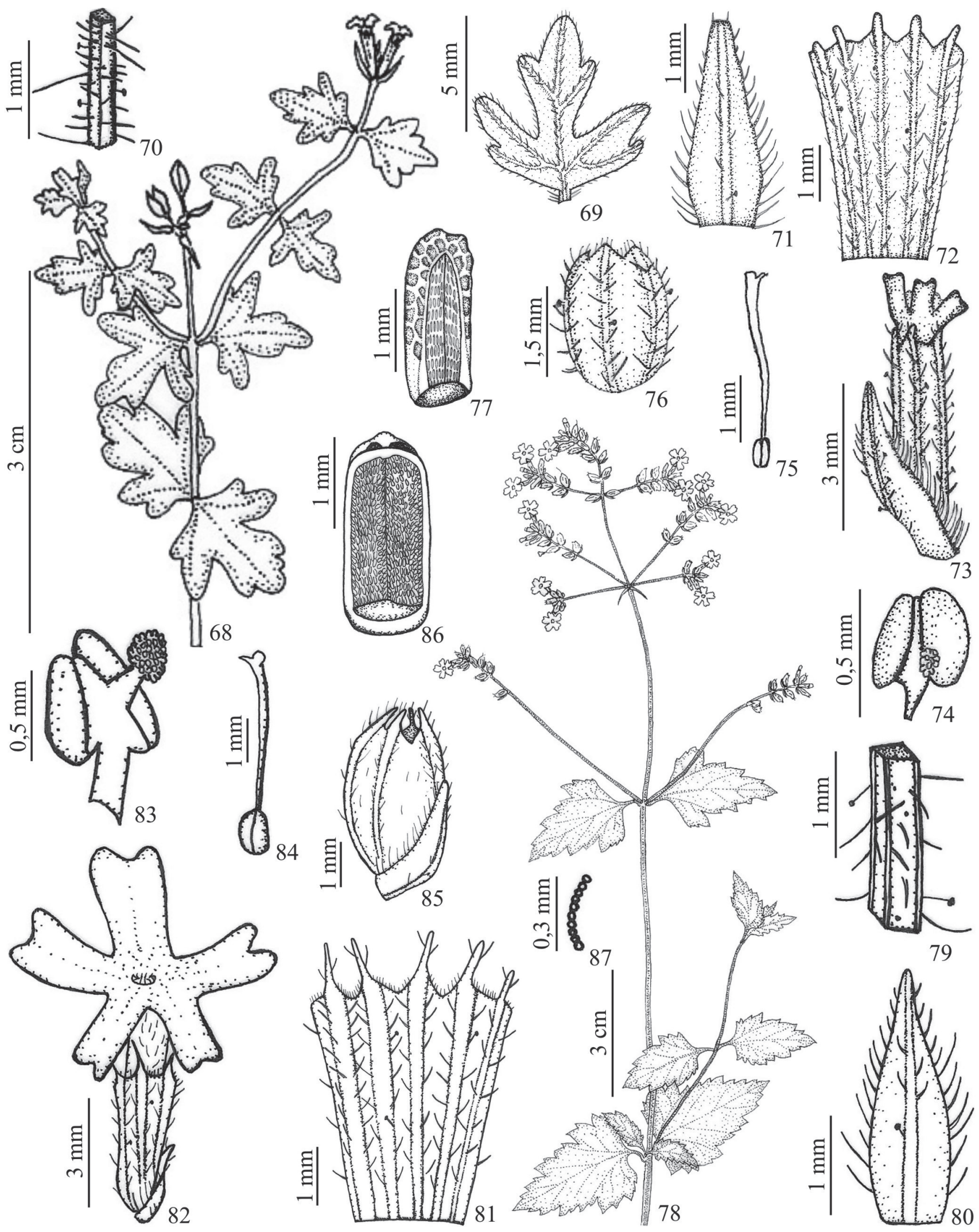

Figuras 68-77. Glandularia jordanensis (Moldenke) O’Leary \& P. Peralta. 68. Ramo. 69. Folha, face abaxial. 70. Indumento do pedúnculo das florescências. 71. Bráctea. 72. Cálice aberto. 73. Flor com bráctea. 74. Antera do par superior de estames com apêndice no conectivo, vista dorsal. 75. Gineceu. 76. Cálice frutífero. 77. Clusa, vista ventral (M. Sobral \& J.R. Stehmann 2742). Figuras 78-87. Glandularia lobata (Vell.) P. Peralta \& Thode. 78. Ramo (V. Thode 147). 79. Indumento do pedúnculo das florescências. 80. Bráctea. 81. Cálice aberto. 82. Flor. 83. Antera do par superior de estames com apêndice no conectivo, vista dorsal. 84. Gineceu. 85. Cálice frutífero com bráctea. 86. Clusa, vista ventral. 87. Tricoma moniliforme ( $V$. Thode 155). 
11. Glandularia marrubioides (Cham.) Tronc., Darwiniana 19: 738. 1975.

Fig. 88-96

Ervas prostradas, com 8-50 cm compr. Caule hirto a híspido, com tricomas tectores longos em várias direções, tectores curtos retrorsos e patentes, e tricomas glandulares pedicelados; entrenós $0,5-6 \mathrm{~cm}$ compr. Folhas inteiras; lâmina 1-4,9x0,5-2,1 cm, obovada a ovalada, ápice agudo a obtuso, base aguda a cuneada, margem inteira da base até a região mediana e serreada da metade até o ápice; face adaxial estrigosa, com tricomas tectores longos e curtos, face abaxial híspida, com tricomas tectores longos e curtos; pecíolo 1 $\mathrm{mm}$ compr. Inflorescências em monobótrios ou pleiobótrios, com 1 par de paracládios simples; florescências 2-3,5×3-3,5 $\mathrm{cm}$, em espigas multifloras, umbeliformes na antese, com raque alongada na frutificação até $6 \mathrm{~cm}$; pedúnculo das florescências hirto a híspido, com tricomas tectores longos em várias direções, tectores curtos retrorsos e patentes, e tricomas glandulares pedicelados. Brácteas 4-7 mm compr., lanceoladas, pubescentes, com tricomas tectores e glandulares pedicelados, margem ciliada. Cálice $9-11 \mathrm{~mm}$ compr., hirto a híspido, com tricomas tectores longos, antrorsos e patentes, mais evidentes sobre as costelas, tectores curtos $\mathrm{e}$ tricomas glandulares pedicelados; lacínias 1,5-2 mm compr., lanceoladas, coniventes no fruto. Corola hipocrateriforme, lilás a roxa, externamente pilosa, tubo $14-18 \mathrm{~mm}$ compr., limbo 14-17 mm diâm. Par superior de estames com apêndices conectivais que não superam as tecas, inclusos. Estilete 12-15 mm compr.; ovário ca. $1 \mathrm{~mm}$ compr. Clusas 3,8-4,5 $\mathrm{mm}$ compr., ápice obtuso, base alargada ou não, face ventral lisa a papilosa, face dorsal reticulada na porção superior e estriada na inferiorOcorre na Argentina, Uruguai e no Brasil (Múlgura 2007). No Rio Grande do Sul é encontrada principalmente nos Campos de Cima da Serra, Planalto Médio, Encosta Superior do Nordeste e Depressão Central. Cresce em campos e em barrancos de beiras de estrada. Possui a face abaxial das folhas com nervuras muito evidentes (Fig. 71). Ver comentários em G. humifusa. Floresce e frutifica de agosto a abril.

Material examinado selecionado: BRASIL. Rio Grande do Sul: Antônio Prado, 6/X/2000, fl., R. Wasum et al. 680 (HUCS); Cruz Alta, 3/X/2007, fl., V. Thode 71 (ICN); Porto Alegre, 21/09/2007, fl. fr., $V$. Thode 29 (ICN); São José dos Ausentes, 20/XI/2007, fl., $V$. Thode 168 (ICN).

12. Glandularia megapotamica (Spreng.) Cabrera \& Dawson, Revista Mus. La Plata, Secc. Bot. 5: 357. 1944.

Fig. 97-104

Ervas ou subarbustos eretos, com 0,3 a mais de $1 \mathrm{~m}$ alt. Caule subglabro a pubescente, com tricomas tectores retrorsos; entrenós 2-12 cm compr. Folhas inteiras; lâmina 2-5,5x0,6-2 cm, oval-lanceolada, ápice agudo, base brevemente atenuada a cuneada, decurrente no pecíolo, margem serreada; face adaxial estrigosa, face abaxial subglabra a estrigosa, com tricomas mais evidentes sobre as nervuras; pecíolo $0,5-1,5 \mathrm{~cm}$ compr. Inflorescências em monobótrios ou pleiobótrios heterotéticos com 1 a 5 pares de paracládios simples; florescências 2-3x4-5,2 cm, em espigas multifloras, umbeliformes na antese, com raque não alongada na frutificação; pedúnculo das florescências subglabro a pubescente, com tricomas tectores retrorsos. Brácteas 1-5 mm compr., oval-lanceoladas, pubescentes, com tricomas tectores e glandulares subsésseis bem distribuídos, margem ciliada. Cálice 10-13 mm compr., pubescente, com tricomas tectores e glandulares subsésseis bem distribuídos, antrorsos; lacínias 0,2-1 mm compr., mucronadas, contortas no fruto. Corola hipocrateriforme, lilás, com tricomas glandulares externamente, tubo 12-18 mm compr., limbo 11-13 mm diâm. Par superior de estames com apêndices conectivais que não superam as tecas, inclusos. Estilete $12-13 \mathrm{~mm}$ compr.; ovário ca. $1 \mathrm{~mm}$ compr. Clusas 4-4,1 mm compr., ápice brevemente agudo projetado para a frente, base alargada, face ventral pouco papilosa a papilosa, face dorsal reticulada na metade superior e estriada na inferior.

Ocorre na Argentina (Províncias de Misiones, Corrientes, Entre Ríos e Buenos Aires), no Uruguai (Departamento de Rivera) e no sul do Brasil. É encontrada no Estado na Serra do Sudeste, em campos, solos úmidos e bordas de mata. Difere de G. guaranitica e G. phlogiflora pela ausência de tricomas glandulares pedicelados no caule ou pedúnculos e pela presença de tricomas glandulares subsésseis nas brácteas e cálice, enquanto nas outras duas espécies os tricomas das brácteas e cálice são glandulares pedicelados. Além destes caracteres, Glandularia megapotamica possui as lacínias do cálice mucronadas, enquanto nas outras duas espécies estas são triangular-lanceoladas, lanceoladas ou subuladas. Ver mais comentários em G. guaranitica e G. hasslerana. Floresce de outubro a março.

Material examinado selecionado: BRASIL. Rio Grande do Sul: Amaral Ferrador, 6/X/1999, fl., A. Knob \& $S$. Bordignon 6142 (UNILASALLE); Piratini, 21/X/2007, fl., $V$. Thode 122 (ICN).

13. Glandularia nana (Moldenke) Tronc., Darwiniana 19(2-4): 738. 1975.

Fig. 105-114

Ervas prostradas, com 6-20 cm compr. Caule híspido, com tricomas tectores e glandulares pedicelados patentes e antrorsos; entrenós $0,5-2 \mathrm{~cm}$ compr. Folhas inteiras; lâmina 0,8-2,5x0,7-1,2 cm, ovalada, ápice obtuso a cuneado, base aguda a cuneada, decurrente no pecíolo, margem crenada; face adaxial estrigosa, com tricomas tectores bem distribuídos, face abaxial estrigosa, com tricomas tectores mais evidentes sobre as nervuras e com poucos tricomas glandulares pedicelados; pecíolo 2-6 mm compr. Inflorescências em monobótrios; florescências 1,5-2x1,5-2 cm, em espigas multifloras, umbeliformes na antese, com raque alongada na frutificação até $4,5 \mathrm{~cm}$; pedúnculo das florescências híspido, 


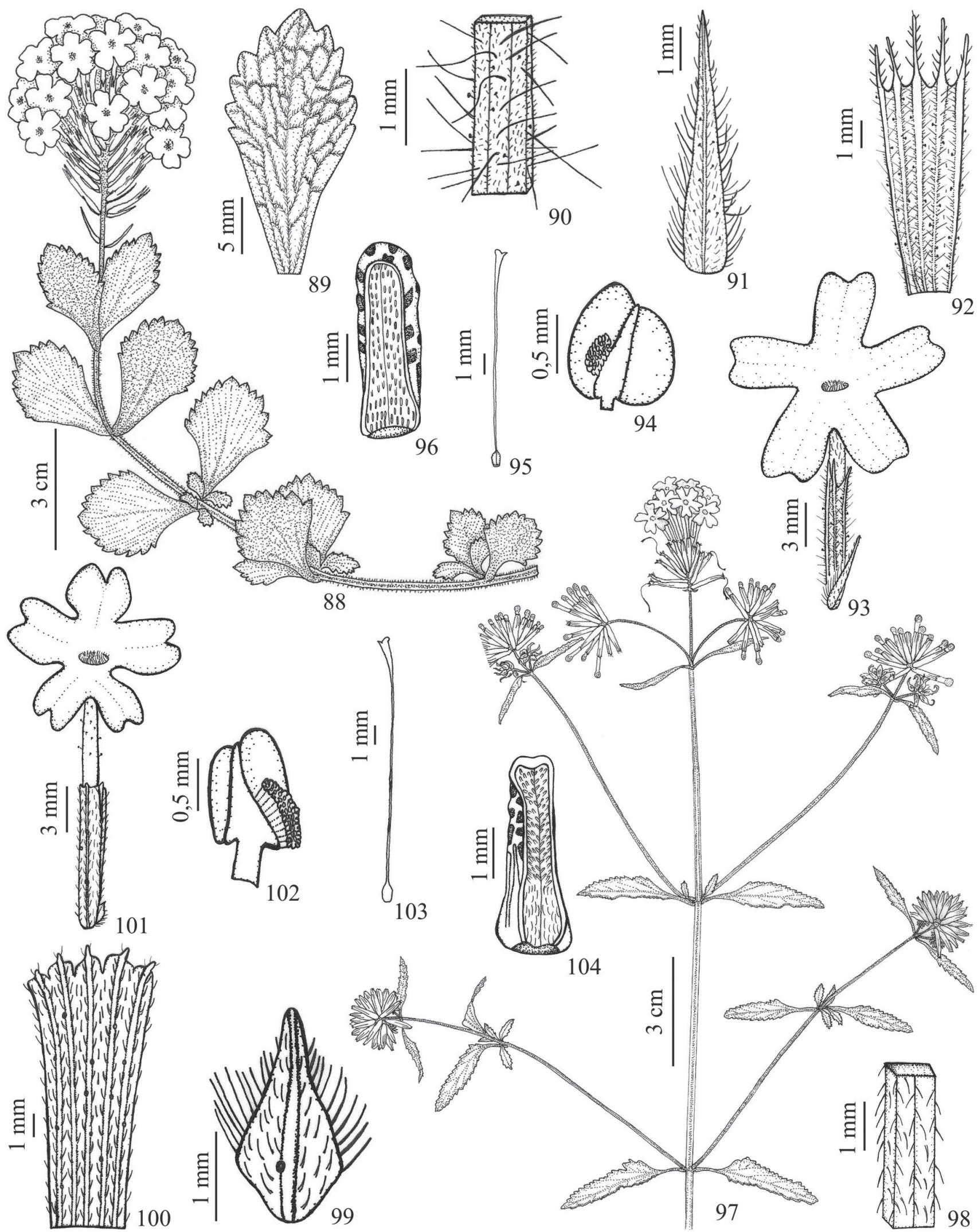

Figuras 88-96. Glandularia marrubioides (Cham.) Tronc. 88. Ramo (V. Thode 64). 89. Folha, face abaxial. 90. Indumento do pedúnculo das florescências. 91. Bráctea. 92. Cálice aberto. 93. Flor. 94. Antera do par superior de estames com apêndice no conectivo, vista dorsal. 95. Gineceu. 96. Clusa, vista ventral ( $V$. Thode 29). Figuras 97-104. Glandularia megapotamica (Spreng.) Cabrera \& Dawson. 97. Ramo. 98. Indumento do pedúnculo das florescências. 99. Bráctea. 100. Cálice aberto. 101. Flor. 102. Antera do par superior de estames com apêndice no conectivo, vista dorsal. 103. Gineceu (V. Thode 122). 104. Clusa, vista ventral (A. Burkart 5127). 
com tricomas tectores e glandulares pedicelados patentes e antrorsos. Brácteas 4-6 mm compr., lanceoladas, com tricomas tectores e glandulares pedicelados, margem ciliada. Cálice 9-10 mm compr., híspido, com tricomas tectores e glandulares pedicelados, antrorsos e patentes, mais evidentes sobre as costelas; lacínias 0,2-1 mm compr., triangular-lanceoladas, contortas no fruto. Corola hipocrateriforme, lilás a roxa, com tricomas glandulares externamente, tubo 15-16 mm compr., limbo 10-13 mm diâm. Par superior de estames sem apêndices conectivais. Estilete 14-15 mm compr.; ovário ca. $1 \mathrm{~mm}$ compr. Clusas $4 \mathrm{~mm}$ compr., ápice obtuso, base não alargada, face ventral lisa, face dorsal reticulada na porção superior e estriada na inferior.

Ocorre na Argentina (Províncias do Chaco e Formosa), no Paraguai e no Brasil, nos estados do Mato Grosso do Sul e Rio Grande do Sul, sendo o primeiro registro de ocorrência para este. Glandularia nana é pouco comum, tendo sido coletados apenas três exemplares no Estado, todos no município de Quaraí. Prefere solos úmidos. Floresce de setembro a fevereiro.

Material examinado: BRASIL. Rio Grande do Sul: Quaraí, 27/II/1979, fl. fr., T.M. Pedersen 12556 (SI); idem, 28/IX/1984, fl., B. Irgang et al. s.n. (ICN 92788); idem, 29/X/2008, fl. fr., I. Boldrini \& R. Setubal 1549 (ICN).

\section{Glandularia peruviana (L.) Small, Man. Southeast. Fl.} 1139. 1933.

Fig. 115-121

Ervas rasteiras ou prostradas, radicantes nos nós, com 10-90 cm compr. Caule híspido, com tricomas tectores e glandulares pedicelados patentes ou retrorsos; entrenós 0,6-8,7 cm compr. Folhas inteiras; lâmina 0,7-5,4x0,5-3,5 $\mathrm{cm}$, ovalada a oval-lanceolada, ápice agudo, base cuneada a obtusa, decurrente no pecíolo, margem serreada, dentada ou inciso-serreada; face adaxial estrigosa, com tricomas tectores bem distribuídos, face abaxial pubescente a estrigosa, com tricomas tectores mais evidentes sobre as nervuras; pecíolo 1-7 mm. Inflorescências em monobótrios ou pleiobótrios heterotéticos com 1 par de paracládios simples; florescências 1,5-3x2-5 cm, em espigas multifloras, umbeliformes na antese, com raque alongada até $9,5 \mathrm{~cm}$ na frutificação; pedúnculo das florescências híspido, com tricomas tectores e glandulares pedicelados patentes ou retrorsos. Brácteas 3,5-7 mm compr., lanceoladas, pilosas, com tricomas tectores e glandulares pedicelados bem distribuídos, margem ciliada. Cálice (8)10-13 mm compr., pubescente a híspido, com tricomas tectores, antrorsos e patentes, e tricomas glandulares pedicelados bem distribuídos; lacínias 0,5-1,5 mm compr., triangular-lanceoladas, coniventes no fruto. Corola hipocrateriforme, vermelha, externamente pilosa, tubo (12)17-21 mm compr., limbo 15-19 mm diâm. Par superior de estames sem apêndices conectivais. Estilete 13-19 mm compr.; ovário ca. $1 \mathrm{~mm}$ compr. Clusas 5-5,5 mm compr., ápice obtuso projetado para a frente, base não alargada, face ventral papilosa, face dorsal reticulada nos dois terços superiores e estriada no restante.

Esta espécie possui ampla distribuição, ocorrendo em diversos países da América do Sul, como no Peru, Bolívia, Paraguai, Argentina e Uruguai (Múlgura 2007). No Rio Grande do Sul é bem distribuída e é comum em solos arenosos, pedregosos, dunas e campos. Difere das demais espécies por possuir a corola vermelha, entretanto, foram encontrados exemplares com corola de tons vermelhos mais claros, chegando ao branco próximo ao centro do limbo. Floresce e frutifica de setembro a abril.

Material examinado selecionado: BRASIL. Rio Grande do Sul: Bagé, 21/X/2007, fl. fr., V. Thode 112 (ICN); Caçapava do Sul, 5/X/2007, fl., V. Thode 98 (ICN); Cambará do Sul, II/1948, fl., B. Rambo 36417 (PACA); Giruá, 17/XI/1974, fl., A.G. Ferreira s.n. (ICN 28950); Montenegro, 5/VII/1949, fl., B. Rambo 43282 (PACA); Santa Maria, 3/X/2007, fl. fr., $V$. Thode 83 (ICN); Santo Antônio das Missões, 6/XII/2007, fl. fr., $V$. Thode 193 (ICN); Soledade, 2/X/2007, fl., $V$. Thode 63 (ICN); Torres, 11/XI/1965, fl., Schultz 3980 (ICN).

\section{Glandularia phlogiflora (Cham.) Schnack \& Covas, Darwiniana 6: 475.1944.}

Fig. 122-130

Ervas ou subarbustos eretos a prostrados, com 0,2-1,5 m alt. Caule piloso a híspido, com tricomas tectores retrorsos e patentes, e tricomas glandulares pedicelados em menor quantidade; entrenós 2-13 cm compr. Folhas inteiras; lâmina 1,4-6,3x0,5-3 cm, oval-lanceolada, ápice agudo, base brevemente atenuada a subtruncada, decurrente no pecíolo, margem serreada a inciso-serreada; face adaxial estrigosa, face abaxial pilosa a estrigosa, com tricomas mais evidentes sobre as nervuras; pecíolo 0,3-1 cm compr. Inflorescências em monobótrios ou pleiobótrios heterotéticos com 1 a 6 pares de paracládios simples; florescências $2-3,5 \times 2,3-5,5 \mathrm{~cm}$, em espigas multifloras, umbeliformes na antese, com raque não alongada na frutificação; pedúnculo das florescências piloso a híspido, com tricomas tectores retrorsos e patentes, e tricomas glandulares pedicelados em menor quantidade. Brácteas 3-7 mm compr., lanceoladas, subglabras a pilosas, com tricomas tectores e poucos glandulares pedicelados, margem ciliada. Cálice 10-16 mm compr., híspido, com tricomas tectores e glandulares pedicelados sobre as costelas, em várias direções, a maioria patentes; lacínias 1-2 mm compr., lanceoladas a subuladas, contortas ou coniventes no fruto. Corola hipocrateriforme, lilás a roxa, com tricomas glandulares externamente, tubo 14-21 mm compr., limbo 17-22 mm diâm. Par superior de estames com apêndices conectivais que não superam as tecas, inclusos. Estilete 15-18 mm compr.; ovário ca. $1 \mathrm{~mm}$ compr. Clusas 3,5-6 mm compr., ápice brevemente agudo projetado para a frente, base alargada, face ventral lisa ou papilosa, face dorsal reticulada na metade superior e estriada na inferior. 


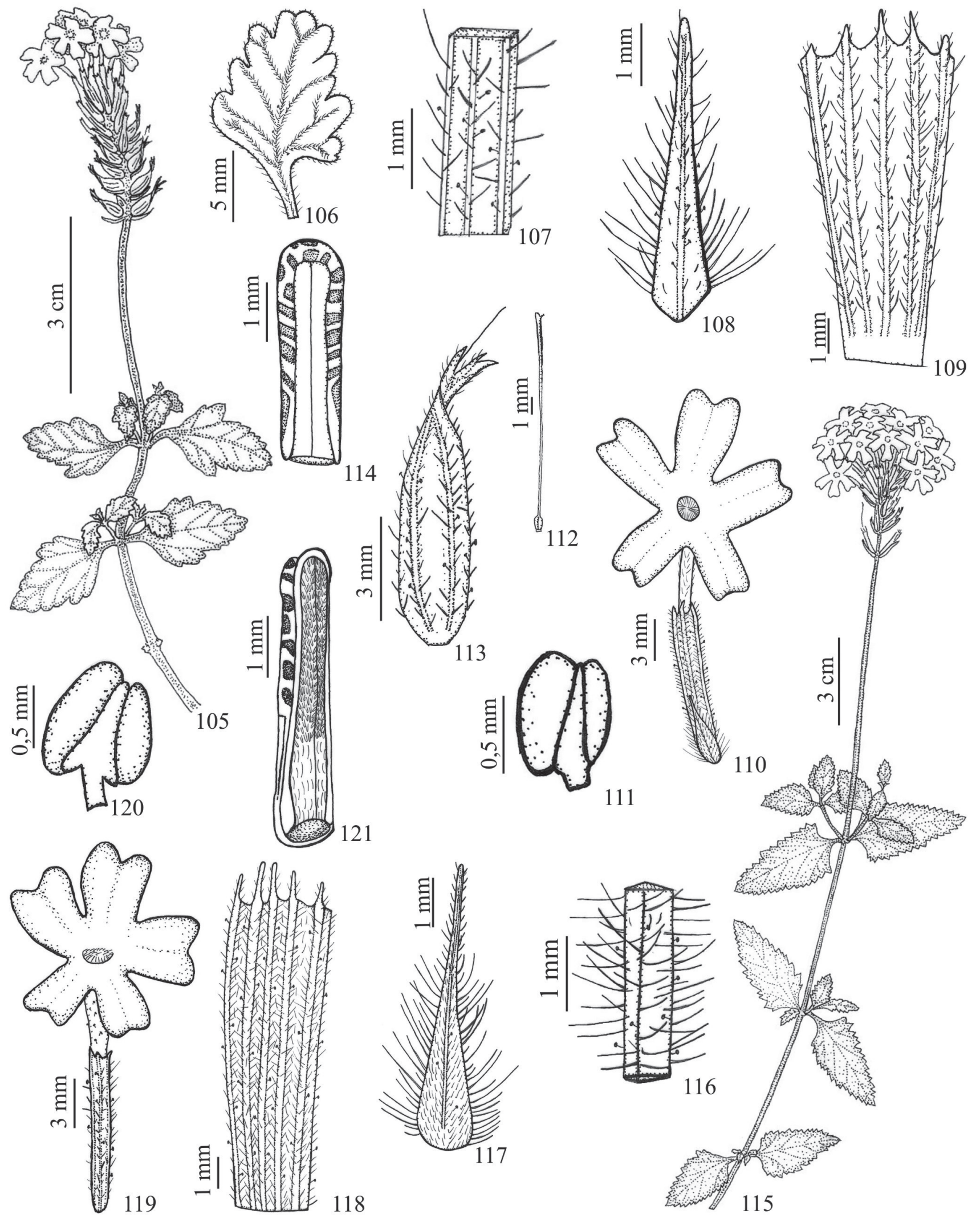

Figuras 105-114. Glandularia nana (Moldenke) Tronc. 105. Ramo. 106. Folha, face abaxial. 107. Indumento do pedúnculo das florescências. 108. Bráctea. 109. Cálice aberto. 110. Flor. 111. Antera do par superior de estames, vista dorsal. 112. Gineceu. 113. Cálice frutífero. 114. Clusa, vista ventral (I. Boldrini \& R. Setubal 1549). Figuras 115-121. Glandularia peruviana (L.) Small. 115. Ramo (L. Eggers 290). 116. Indumento do pedúnculo das florescências. 117. Bráctea. 118. Cálice aberto. 119. Flor. 120. Antera do par superior de estames, vista dorsal. 121. Clusa, vista lateral (V. Thode 83). 
Ocorre no sul do Brasil e na região nordeste da Argentina (Províncias de Corrientes e Misiones) (Troncoso 1971; Múlgura 2007). No Estado foi encontrada principalmente nos de Cima da Serra e também na Encosta Superior do Nordeste, Encosta Inferior do Nordeste, Depressão Central, Planalto Médio, Alto Uruguai e Litoral, em campos, borda de mata, beiras de estrada, banhados e turfeiras. Ver comentários em G. guaranitica, G. hasslerana e G. megapotamica. Floresce e frutifica de setembro a março.

Material examinado selecionado: BRASIL. Rio Grande do Sul: Cambará do Sul, 18/XI/2007, fl., V. Thode 146 (ICN); Canela, 21/XII/1947, fl., Emrich \& Rambo s.n. (PACA 35908); Caxias do Sul, 11/XI/2005, fl. fr., R. Wasum 3298 (HUCS); Erechim, 19/X/1995, fl., A. Butzke et al. s.n. (HUCS 11105); Porto Alegre, 28/IX/1949, fl., B. Rambo 44165 (PACA); Soledade, 2/X/2007, fl. fr., $V$. Thode 60 (ICN).

16. Glandularia platensis (Spreng.) Schnack \& Covas, Darwiniana 6(3): 475. 1944.

Fig. 131-139

Ervas prostradas, com 8-50 cm compr. Caule híspido, com tricomas tectores e glandulares pedicelados em várias direções, a maioria patentes; entrenós 0,6-4,5 cm compr. Folhas inteiras; lâmina $0,8-4 \times 0,7-2,5 \mathrm{~cm}$, oval-lanceolada a lanceolada, ápice agudo, base obtusa a aguda, decurrente no pecíolo, margem serreada a incisa; face adaxial estrigosa, com tricomas tectores bem distribuídos, face abaxial estrigosa a pubescente, com tricomas tectores e glandulares pedicelados mais evidentes sobre as nervuras; pecíolo 1-6 mm compr. Inflorescências em monobótrios ou pleiobótrios heterotéticos com 1 par de paracládios simples; florescências 2,7-3x2,5-3,8 $\mathrm{cm}$, em espigas multifloras, umbeliformes na antese, com raque alongada na frutificação até $9,2(14,5) \mathrm{cm}$; pedúnculo das florescências híspido, com tricomas tectores e glandulares pedicelados em várias direções, a maioria patentes. Brácteas 5-7,5 mm compr., lanceoladas, pilosas, com tricomas tectores e glandulares pedicelados bem distribuídos, margem ciliada. Cálice 13-16 mm compr., híspido, com tricomas tectores e glandulares pedicelados, antrorsos e patentes, mais evidentes sobre as costelas; lacínias 1-2 mm compr., triangularlanceoladas, coniventes no fruto. Corola hipocrateriforme, branca, com tricomas glandulares externamente, tubo 20-25 mm compr., limbo 15-17 mm diâm. Par superior de estames sem apêndices conectivais. Estilete $21 \mathrm{~mm}$ compr.; ovário ca. $1 \mathrm{~mm}$ compr. Clusas 4,5-5,2 mm compr., ápice obtuso, base não alargada, face ventral lisa a papilosa, face dorsal reticulada nos dois terços superiores e estriada no restante.

Ocorre no sul do Brasil, no Uruguai, Argentina e Paraguai (Lombardo 1983; Múlgura 2007). No Rio Grande do Sul é encontrada predominantemente na Campanha, principalmente em campos pedregosos. Difere das outras espécies por possuir a corola branca. Floresce e frutifica de outubro a março.
Material examinado selecionado: BRASIL. Rio Grande do Sul: Alegrete, 19/III/2005, fl., A.M. Girardi-Deiro et al. 1876 (CNPO); Caçapava do Sul, 11/X/2000, fl. fr., $S$. Bordignon et al. 1939 (HERULBRA); Quaraí, 29/X/2008, fl. fr., R. Setubal \& I. Boldrini 733 (ICN).

17. Glandularia pulchra (Moldenke) Botta, Hickenia 2(28): 128. 1995.

Fig. 140-147

Ervas ou subarbustos eretos a prostrados, com 30-90 cm alt. Caule hirto, com tricomas tectores, retrorsos e patentes, e tricomas glandulares pedicelados; entrenós 3-8 cm compr. Folhas inteiras; lâmina 4-11x0,9-2,1 cm, lanceolada, ápice agudo, base aguda, decurrente no pecíolo, margem serreada; face adaxial estrigosa, com tricomas tectores bem distribuídos, face abaxial estrigosa, com tricomas mais evidentes sobre as nervuras; pecíolo 3-8 mm compr. Inflorescências em monobótrios ou pleiobótrios, com 1 par de paracládios simples; florescências $2 \times 2,5 \mathrm{~cm}$, em espigas multifloras, umbeliformes na antese, com raque alongada na frutificação até $7 \mathrm{~cm}$; pedúnculo das florescências hirto, com tricomas tectores e glandulares pedicelados, em várias direções, em maior quantidade abaixo da florescência. Brácteas 5 mm compr., lanceoladas, pilosas, com tricomas tectores e glandulares pedicelados, margem ciliada. Cálice 9-10 mm compr., híspido, com tricomas tectores, antrorsos e patentes, e tricomas glandulares pedicelados mais evidentes sobre as costelas; lacínias 0,2-0,5 mm compr., triangulares, contortas no fruto. Corola hipocrateriforme, lilás, tubo 14-15 mm compr., limbo 8-10 mm diâm., externamente pilosa. Par superior de estames com apêndices conectivais que superam as tecas, exsertos. Estilete $13 \mathrm{~mm}$ compr.; ovário ca. $1 \mathrm{~mm}$ compr. Clusas $4 \mathrm{~mm}$ compr., ápice obtuso projetado para a frente, base não alargada, face ventral lisa, face dorsal com a porção superior reticulada e a inferior estriada.

Esta espécie ocorre no sul do Brasil, nos estados do Paraná, Santa Catarina e Rio Grande do Sul, e também no Uruguai e Argentina (Províncias de Corrientes e Misiones). É uma espécie pouco coletada no Estado, diferindo das demais por suas grandes folhas inteiras e lanceoladas. Floresce e frutifica de outubro a janeiro.

Material examinado: BRASIL. Rio Grande do Sul: Cachoeira do Sul, 9/I/1902, fl., G.O.A. Malme 1026 (NY); Pareci Novo, 3/X/1945, fl. fr., E. Henz 29682 (PACA, NY).

18. Glandularia rectiloba (Moldenke) P. Peralta \& Thode, Rodriguésia 61(1): S32. 2010.

Fig. 148-155

Ervas rasteiras, radicantes nos nós, com 0,1-1 m compr. Caule subglabro, com poucos tricomas tectores antrorsos; entrenós 0,5-4 cm compr. Folhas pinatissectas, trissectas, podendo ter os segmentos partidos, lineares; lâmina 1,64x0,9-3 cm, decurrente no pecíolo; face adaxial pubescente, com poucos tricomas tectores adpressos, face abaxial pu- 


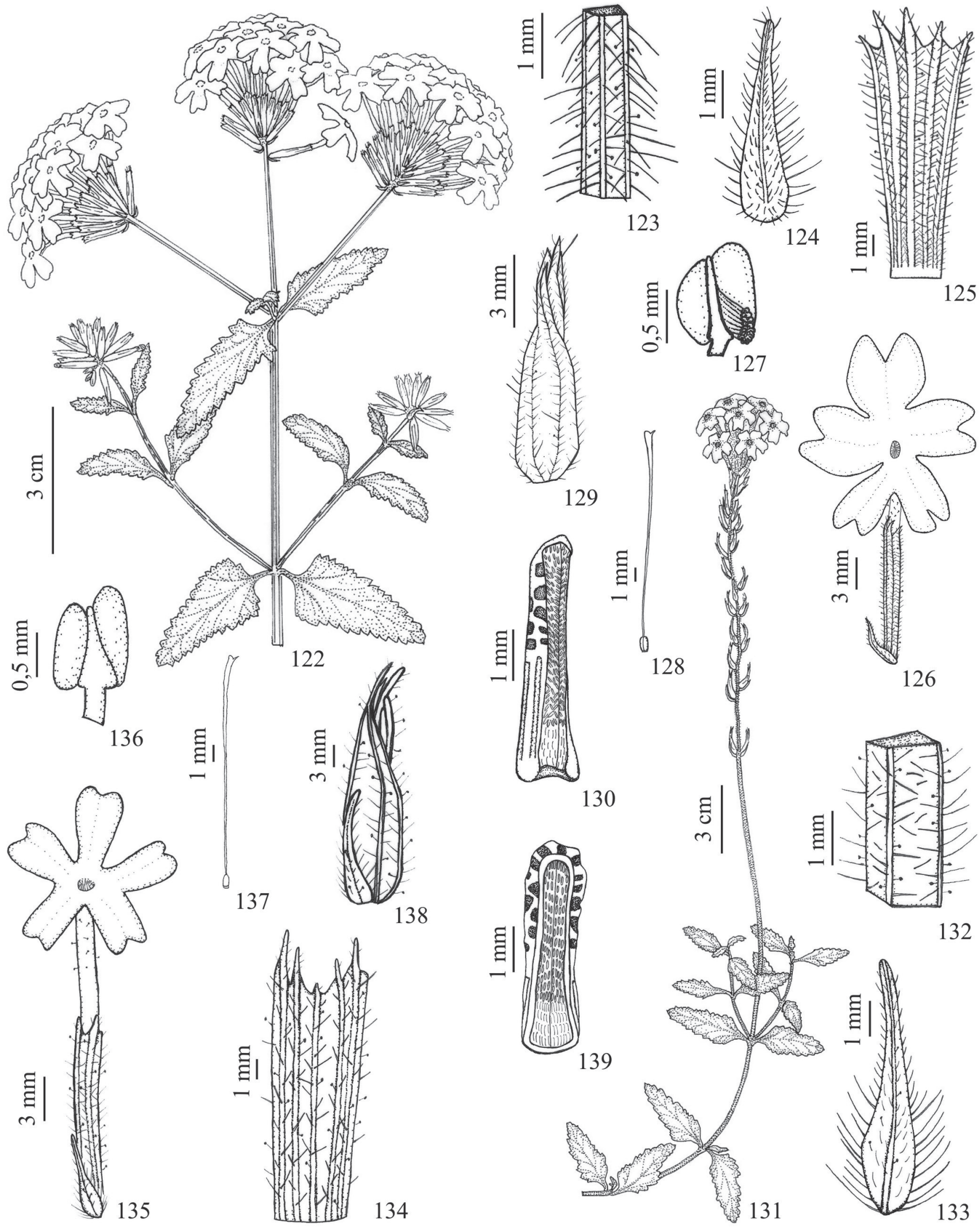

Figuras 122-130. Glandularia phlogiflora (Cham.) Schnack \& Covas. 122. Ramo (V. Thode 51). 123. Indumento do pedúnculo das florescências. 124. Bráctea. 125. Cálice aberto. 126. Flor. 127. Antera do par superior de estames com apêndice no conectivo, vista dorsal. 128. Gineceu. 129. Cálice frutífero. 130. Clusa, vista lateral (V. Thode 172). Figuras 131-139. Glandularia platensis (Spreng.) Schnack \& Covas. 131. Ramo (A.M. Girardi-Deiro et al. 1801). 132. Indumento do pedúnculo das florescências. 133. Bráctea. 134. Cálice aberto. 135. Flor. 136. Antera do par superior de estames, vista dorsal. 137. Gineceu. 138. Cálice frutífero. 139. Clusa, vista ventral (S. Bordignon 1939). 
bescente, com tricomas tectores adpressos; pecíolo 0,4-1,5 $\mathrm{cm}$ compr. Inflorescências em monobótrios ou pleiobótrios heterotéticos com 1 par de paracládios simples; florescências de $2 \times 3 \mathrm{~cm}$, em espigas multifloras, umbeliformes na antese, com raque alongada na frutificação até $9 \mathrm{~cm}$ compr.; pedúnculo das florescências subglabro, com poucos tricomas tectores adpressos, antrorsos. Brácteas 2,5-3,3 mm compr., oval-lanceoladas, pubescentes, com tricomas tectores e glandulares subsésseis, margem ciliada. Cálice 9-11 mm compr., pubescente, com tricomas tectores adpressos e antrorsos, e tricomas glandulares subsésseis, bem distribuídos; costelas pouco evidentes; lacínias 0,5-1 mm compr., triangular-lanceoladas, coniventes no fruto. Corola hipocrateriforme, roxa, externamente glabra, tubo 14-18 mm compr., limbo 8-9 mm diâm. Par superior de estames com apêndices conectivais que superam ou não as tecas, exsertos ou inclusos. Estilete 13-15 mm compr.; ovário ca. $1 \mathrm{~mm}$ compr. Clusas 6-7 mm compr., ápice agudo, base alargada, face ventral papilosa, face dorsal reticulada na porção superior e estriada no restante.

O material tipo era o único conhecido para a espécie, até a realização deste trabalho. Glandularia rectiloba foi encontrada até o momento, apenas no município de Rosário do Sul, nos bancos de areia das praias ao longo do rio Santa Maria. Difere das demais espécies por possuir folhas com longos segmentos lineares e pecíolo longo e cálice com costelas pouco evidentes. Floresce e frutifica em janeiro (provavelmente também em dezembro).

Material examinado: BRASIL. Rio Grande do Sul: Rosário do Sul, 20/I/1973, fl., A. Krapovickas et al. 22825 (CTES, SI); idem, 19/I/2009, fl. fr., V. Thode 230 (ICN).

\section{Glandularia scrobiculata (Griseb.) Tronc., Darwiniana} 19(2-4): 738. 1975.

Fig. 156-163

Ervas ou subarbustos eretos, com 4,2-1 m alt. Caule hirto, com tricomas tectores, patentes e retrorsos, e tricomas glandulares pedicelados; entrenós 2-12,5 cm compr. Folhas inteiras; lâmina 1,7-7x0,6-5 cm, oval-lanceolada, ápice agudo, base breve atenuada, decurrente no pecíolo, margem irregularmente inciso-serreada; face adaxial estrigosa, com tricomas tectores bem distribuídos, face abaxial estrigosa, com tricomas mais evidentes sobre as nervuras; pecíolo 0,5-3,7 cm compr. Inflorescências em monobótrios ou pleiobótrios heterotéticos com 1 par de paracládios simples; florescências 1,6-2,7x3,3-3,6 cm, em espigas multifloras, umbeliformes na antese, com raque alongada na frutificação até $5 \mathrm{~cm}$; pedúnculo das florescências hirto, com tricomas tectores, patentes e retrorsos, e tricomas glandulares pedicelados. Brácteas 3,1-5 mm compr., lanceoladas, pilosas, com tricomas tectores e glandulares pedicelados, margem ciliada. Cálice 9-10 mm compr., híspido, com tricomas tectores antrorsos e tricomas glandulares pedicelados principalmente sobre as costelas; lacínias 0,8-1,5 mm compr., triangularlanceoladas, coniventes no fruto. Corola hipocrateriforme, lilás, externamente glabra, tubo 12-15 mm compr., limbo 8-9 mm diâm. Par superior de estames com apêndices conectivais que superam as tecas, exsertos. Estilete 11-12 mm compr.; ovário ca. $1 \mathrm{~mm}$ compr. Clusas 2-3,5 mm compr., ápice obtuso projetado para a frente, base não alargada, face ventral lisa, face dorsal com a porção superior reticulada e a inferior estriada.

Ocorre na Argentina, nas Províncias de Misiones, Salta e Jujuy e no Brasil, no Rio Grande do Sul, onde é encontrada na Encosta Superior do Nordeste e nas Missões. Em material herborizado geralmente as folhas apresentam a face adaxial mais escura que a abaxial, podendo apresentar consistência membranácea. Floresce e frutifica de outubro a novembro.

Material examinado: BRASIL. Rio Grande do Sul: Nova Roma do Sul, XI/2004. fl. fr., J. Larocca s.n. (PACA 97350); Pirapó, 24/V/1989, fl., sem coletor (MPUC 7377); Veranópolis, 16/IX/1971, fl., J.C. Lindeman \& B.E. Irgang s.n. (ICN 8111); idem, 18/X/1986, fl., G. Grazziotin s.n. (HUCS 2135).

20. Glandularia selloi (Spreng.) Tronc., Darwiniana 13(24): 481.1964.

Fig. 164-173

Ervas rasteiras, radicantes nos nós, com 15-92 cm compr. Caule pubescente a estrigoso, com tricomas tectores retrorsos; entrenós 0,3-9,5 cm compr. Folhas pinatissectas, 3 a 5 lobos divididos em 2 ou mais segmentos oblongos ou obovados; lâmina 0,7-4,5x0,6-3,7 cm, decurrente no pecíolo; face adaxial estrigosa, com tricomas tectores bem distribuídos, face abaxial estrigosa, com tricomas tectores principalmente sobre as nervuras, com ou sem tricomas glandulares subsésseis; pecíolo 0,1-1 cm compr. Inflorescências em monobótrios ou pleiobótrios heterotéticos com 1 par de paracládios simples; florescências 1,4-2,5x1,5-3,7 cm, em espigas multifloras, umbeliformes na antese, com raque alongada na frutificação até $7 \mathrm{~cm}$; pedúnculo das florescências hirto, com tricomas tectores e glandulares pedicelados, retrorsos e patentes. Brácteas 4-6 mm compr., lanceoladas, pubescentes a subglabras, com tricomas tectores na nervura principal e tricomas glandulares subsésseis, margem ciliada. Cálice 7,5-9 mm compr., pubescente a estrigoso, com tricomas tectores antrorsos mais evidentes sobre as costelas, e tricomas glandulares subsésseis; lacínias 1-2,5 mm compr., triangular-lanceoladas, coniventes ou contortas no fruto. Corola hipocrateriforme, lilás a roxa, externamente pilosa, tubo 12-13 mm compr., limbo 7-10 mm diâm. Par superior de estames com apêndices conectivais que superam as tecas, exsertos. Estilete 10-12 mm compr.; ovário ca. $1 \mathrm{~mm}$ compr. Clusas 2-3 mm compr., ápice obtuso, base não alargada, face ventral lisa a papilosa, face dorsal com os dois terços superiores reticulados e o restante estriado.

Ocorre no sul do Brasil e, segundo Lombardo (1983), também no Uruguai. Apresenta ampla ocorrência no Estado, sendo abundante nas dunas do Litoral e em diversas 


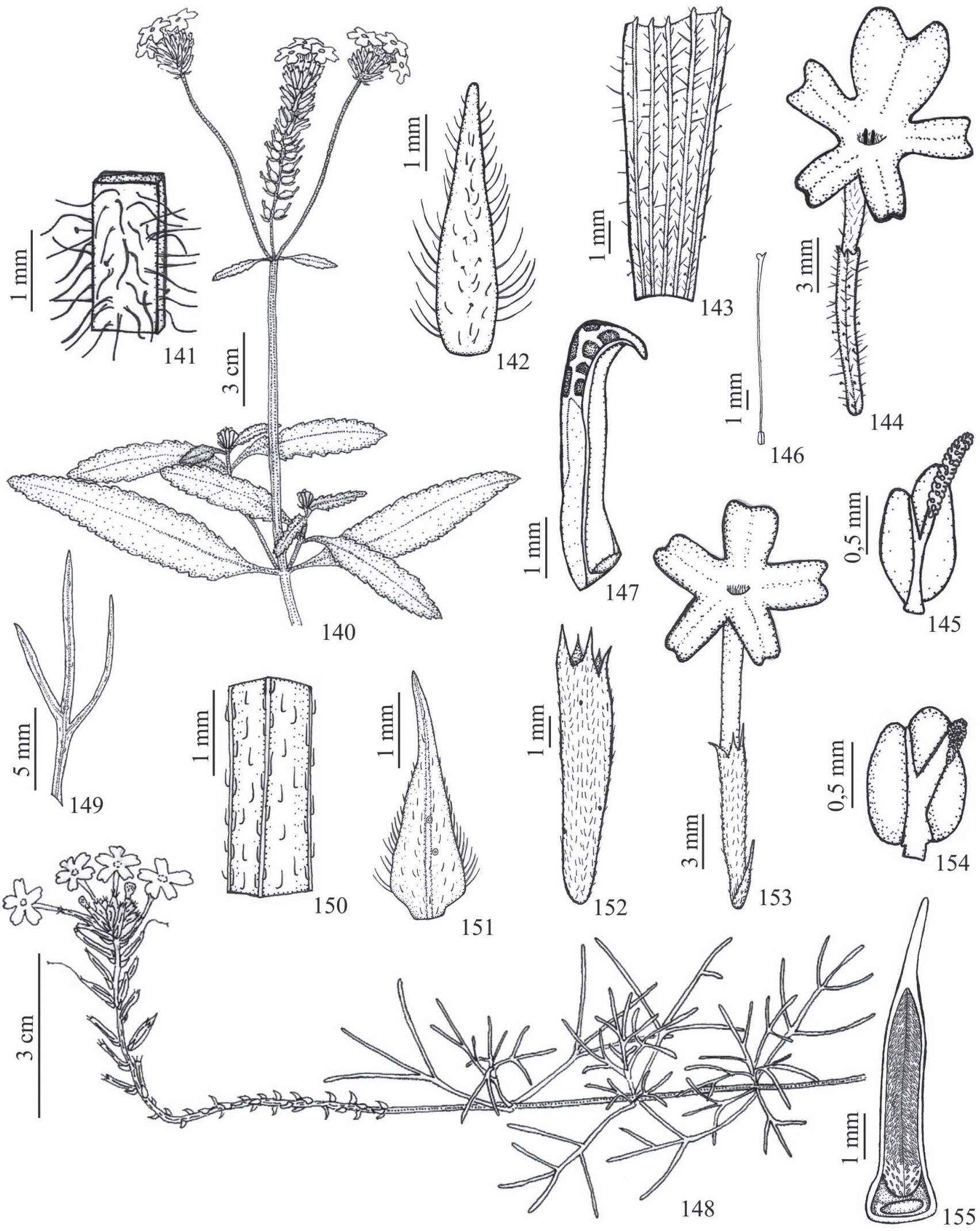

Figuras 140-147. Glandularia pulchra (Moldenke) Botta. 140. Ramo. 141. Indumento do pedúnculo das florescências. 142. Bráctea. 143. Cálice aberto. 144. Flor. 145. Antera do par superior de estames com apêndice no conectivo, vista dorsal. 146. Gineceu. 147. Clusa, vista lateral (E. Henz s.n., PACA 29682). Figuras 148-155. Glandularia rectiloba (Moldenke) P. Peralta \& Thode. 148. Ramo (V. Thode 230). 149. Folha, face abaxial (A. Krapovickas 22825). 150. Indumento do pedúnculo das florescências (V. Thode 230). 151. Bráctea. 152. Cálice. 153. Flor (A. Krapovickas 22825). 154. Antera do par superior de estames com apêndice no conectivo, vista dorsal. 155. Clusa, vista ventral (V. Thode 230). 
outras regiões. Pode crescer isolada ou em populações. É encontrada nos campos, terrenos arenosos, úmidos, turfeiras, áreas degradadas e beiras de estrada. É bastante semelhante a $G$. tenera, da qual difere por possuir tricomas retrorsos no pedúnculo e corola pilosa externamente. Ver comentários em $G$. catharinae. Floresce e frutifica de setembro a abril.

Material examinado selecionado: BRASIL. Rio Grande do Sul: Bagé, 8/IX/2006, fl. fr., H. Longhi-Wagner \& $R$. Schmidt 10148 (ICN); Caçapava do Sul, 30/X/1999, fl. fr., R. Wasum 212 (HUCS); Manoel Viana, 5/XII/2007, fl. fr., V. Thode 186 (ICN); Pelotas, 17/III/1978, fl., C.S.A. Martins s.n. (MPUC 9916); Santa Maria, 21/VIII/1998, fl., R. Záchia 2894 (SMDB); Tramandaí, 7/IX/2007, fl. fr., $V$. Thode 11 (ICN); Tupanciretã, 3/X/2007, fl., V. Thode 79 (ICN).

\section{Glandularia sessilis (Cham.) Tronc., Fl. Il. Entre Ríos} 6(5): 247. 1979.

Fig. 174-181

Ervas eretas a prostradas, com $11-59 \mathrm{~cm}$ alt. Caule subglabro, com tricomas tectores em maior quantidade em direção ao ápice, antrorsos; entrenós 1-4,5 cm compr. Folhas inteiras; lâmina 2-6x0,2-0,8 cm, linear-lanceolada a elíptica, ápice agudo, base subauriculada, brevemente decurrente no caule, margem inteira a levemente serreada; face adaxial estrigosa, face abaxial glabra; folhas sésseis. Inflorescências em monobótrios; florescências 1,3-1,9x1,5-2 cm, em espigas multifloras, umbeliformes na antese, com raque alongada na frutificação até $3,8 \mathrm{~cm}$; pedúnculo das florescências híspido, com tricomas tectores em várias direções, sendo a maioria patentes, e tricomas glandulares pedicelados. Brácteas 4-9 mm compr., lanceoladas, ápice agudo, subglabras, com tricomas tectores e glandulares pedicelados, principalmente sobre a nervura central, margem ciliada. Cálice 6-7 mm compr., híspido, com tricomas tectores antrorsos e tricomas glandulares pedicelados sobre as costelas; lacínias 0,2-0,7 mm compr., triangular-lanceoladas, coniventes no fruto. Corola hipocrateriforme, lilás a roxa, externamente pilosa, tubo 12-13 mm compr., limbo 10 mm diâm. Par superior de estames com apêndices conectivais que não superam as tecas, inclusos. Estilete 11-12 mm compr.; ovário ca. $1 \mathrm{~mm}$ compr. Clusas 2,1 $\mathrm{mm}$, ápice obtuso, base não alargada, face ventral lisa, face dorsal com a porção superior reticulada e a inferior estriada.

Ocorre no sul do Brasil, Paraguai, Uruguai e na região nordeste da Argentina, geralmente em banhados e campos (Troncoso 1979). No Rio Grande do Sul apresenta poucos registros, tendo sido encontrada na Campanha, Missões e Serra do Sudeste. É muito semelhante a G. stellarioides, pois ambas possuem folhas sésseis e brevemente decurrentes no caule. Glandularia sessilis possui brácteas, cálice e corola menores em comprimento e folhas com face adaxial estrigosa, enquanto que G. stellarioides possui brácteas (que ultrapassam o cálice), cálice e corola maiores em comprimento e a face adaxial das folhas geralmente glabra. Floresce e frutifica de outubro a dezembro.
Material examinado: BRASIL. Rio Grande do Sul: Bagé, 20/X/2007, fl., V. Thode 111 (ICN); Canguçú, 22/X/2008, fl., R. Schmidt s.n. (ICN 159070); São Borja, 6/ XII/2007, fl. fr., V. Thode 202 (ICN); São Gabriel, 1944, fl., B. Rambo 25786 (PACA).

22. Glandularia stellarioides (Cham.) Schnack \& Covas, Bol. Soc. Argent. Bot. 1: 284. 1946.

Fig. 182-188

Ervas eretas a prostradas, com $28-40 \mathrm{~cm}$ alt. Caule subglabro, com tricomas tectores em maior quantidade em direção ao ápice, antrorsos; entrenós 1,3-3,5 cm compr. Folhas inteiras; lâmina 2,4-7,6x0,3-0,7 cm, linear-lanceolada, ápice agudo, brevemente decurrente no caule, margem inteira, estrigosa; face adaxial glabra, face abaxial glabra, com poucos tricomas sobre a nervura principal; folhas sésseis. Inflorescências em monobótrios; florescências $2 \times 2,5 \mathrm{~cm}$, em espigas multifloras, umbeliformes na antese, com raque alongada na frutificação até $4,5 \mathrm{~cm}$; pedúnculo das florescências híspido, com tricomas tectores em várias direções, sendo a maioria patentes, e tricomas glandulares pedicelados. Brácteas 12-15 mm compr., lanceoladas, subuladas, subglabras, com tricomas tectores e glandulares pedicelados, principalmente sobre a nervura central, margem ciliada. Cálice 7-9 mm compr., híspido, com tricomas tectores antrorsos e tricomas glandulares pedicelados sobre as costelas; lacínias 1,3-2,5 mm compr., lanceoladas a subuladas, coniventes no fruto. Corola hipocrateriforme, lilás a roxa, externamente pilosa, tubo 14-15 mm compr., limbo 7-8 $\mathrm{mm}$ diâm. Par superior de estames com apêndices conectivais que não superam as tecas, inclusos. Estilete $14 \mathrm{~mm}$ compr.; ovário ca. $1 \mathrm{~mm}$ compr. Clusas 3,1-3,5 mm compr., ápice obtuso, base alargada ou não, face ventral lisa a papilosa, face dorsal com a porção superior reticulada e a inferior estriada.

Ocorre na Argentina (Províncias de Corrientes e Misiones), Paraguai e Brasil, em campos e banhados. No Rio Grande do Sul existem apenas três coletas até o momento, todas provenientes do município de Tupanciretã, na região do Planalto Médio. Ver comentários em G. sessilis. Floresce e frutifica de outubro a fevereiro.

Material examinado: BRASIL. Rio Grande do Sul: Tupanciretã, 26/I/1942, fl., B. Rambo 10156 (PACA); idem, 28/I/1942, fl., B. Rambo 9555 (PACA); idem, 29/I/1942, fl. fr., B. Rambo 9758 (PACA).

23. Glandularia subincana Tronc., Darwiniana 13(2-4): 478, f. 5. 1964.

Fig. 189-198

Ervas rasteiras, com 8-40 cm compr. Caule híspido, com tricomas tectores retrorsos e patentes; entrenós $0,7-2,5 \mathrm{~cm}$ compr. Folhas pinatissectas, com os lobos divididos em 2 ou mais segmentos oblongos; lâmina 1-2,7x0,6-2,3 cm, decurrente no pecíolo; face adaxial estrigosa, com tricomas tectores bem distribuídos, face abaxial estrigosa, com tri- 


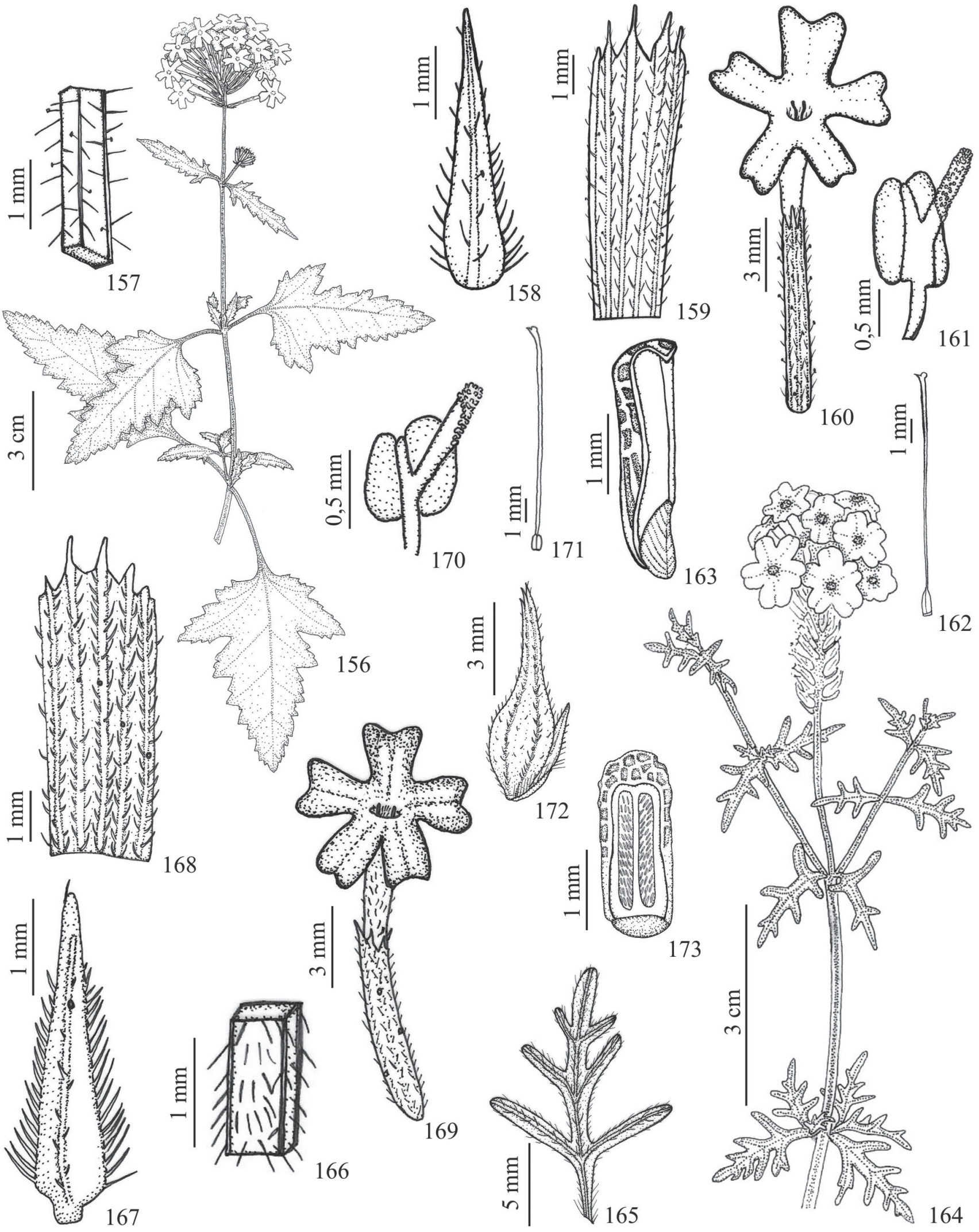

Figuras 156-163. Glandularia scrobiculata (Griseb.) Tronc. 156. Ramo (G. Grazziotin s.n., HUCS 2135). 157. Indumento do pedúnculo das florescências. 158. Bráctea. 159. Cálice aberto. 160. Flor. 161. Antera do par superior de estames com apêndice no conectivo, vista dorsal. 162. Gineceu. 163. Clusa, vista lateral $(J$. Larocca s.n., PACA 97350). Figuras 164-173. Glandularia selloi (Spreng.) Tronc. 164. Aspecto geral da planta. (F. Marchett 63). 165. Folha, face abaxial. 166. Indumento do pedúnculo das florescências. 167. Bráctea. 168. Cálice aberto. 169. Flor. 170. Antera do par superior de estames com apêndice no conectivo, vista dorsal. 171. Gineceu. 172. Cálice frutífero com bráctea. 173. Clusa, vista ventral (V. Thode 75). 
comas tectores principalmente sobre as nervuras e tricomas glandulares subsésseis; pecíolo 2-5 mm compr. Inflorescências em monobótrios ou pleiobótrios heterotéticos com 1 par de paracládios simples; florescências 1,5-2x2-2,5 cm, em espigas multifloras, umbeliformes na antese, com raque alongada na frutificação até $7 \mathrm{~cm}$; pedúnculo das florescências híspido, com tricomas tectores retrorsos e patentes. Brácteas 3-5 mm compr., lanceoladas, pubescentes, com tricomas tectores e tricomas glandulares subsésseis, margem ciliada. Cálice 7-9 mm compr., pubescente, com tricomas tectores antrorsos, podendo ser retrorsos na metade inferior, e tricomas glandulares subsésseis, bem distribuídos; lacínias 0,7-1,7 mm compr., triangular-lanceoladas, coniventes no fruto. Corola hipocrateriforme, lilás, externamente glabra, tubo 10-12 mm compr., limbo 7 mm diâm. Par superior de estames com apêndices conectivais que superam as tecas, exsertos. Estilete 10-12 mm compr.; ovário ca. $1 \mathrm{~mm}$ compr. Clusas 3-3,5 mm compr., ápice obtuso, base alargada ou não, face ventral lisa a papilosa, face dorsal com a porção superior reticulada e a inferior estriada.

Ocorre no Uruguai e Argentina, na Província de Entre Ríos (Troncoso 1964, 1979; Múlgura 2007), sendo esta a primeira citação para o Rio Grande do Sul, onde é encontrada na Campanha e Missões, em solos arenosos. Pode ser confundida com G. tomophylla, a qual possui corola pilosa externamente. Floresce e frutifica de setembro a dezembro.

Material examinado selecionado: BRASIL. Rio Grande do Sul: Santana do Livramento, 8/XI/2008, fl. fr., $A$. Schneider et al. 1612 (ICN); Santo Antônio das Missões, 6/ XII/2007, fl. fr., V. Thode 197 (ICN); São Borja, 5/XII/2007, fl. fr., $V$. Thode 191 (ICN); Uruguaiana, 8/XII/2007, fl. fr., V. Thode 218 (ICN).

24. Glandularia tenera (Spreng.) Cabrera, Man. Fl. Al. Buenos Aires: 398. 1953.

Fig. 199-207

Ervas rasteiras, radicantes nos nós, com $12-50 \mathrm{~cm}$ compr. Caule piloso, com tricomas tectores adpressos e antrorsos; entrenós 0,5-6 cm compr. Folhas pinatissectas, 3 a 5 lobos divididos em 2 ou mais segmentos lineares ou oblongos; lâmina 1-4x1-4,3 cm, decurrente no pecíolo; face adaxial estrigosa, com tricomas tectores adpressos, face abaxial estrigosa, com tricomas tectores adpressos e tricomas glandulares subsésseis; pecíolo 0,3-1 cm compr. Inflorescências em monobótrios ou pleiobótrios heterotéticos com 1 par de paracládios simples; florescências 1,3-2x1,9-3,5 cm, em espigas multifloras, umbeliformes na antese, com raque alongada na frutificação até $7 \mathrm{~cm}$; pedúnculo das florescências piloso, com tricomas tectores adpressos e antrorsos. Brácteas 2,5-4,5 mm compr., oval-lanceoladas, pubescentes, com tricomas tectores e glandulares subsésseis, margem ciliada com menos tricomas em direção ao ápice. Cálice 7-9 mm compr., pubescente, com tricomas tectores adpressos e antrorsos, e tricomas glandulares subsésseis, bem distribuídos; lacínias
0,8-2 mm compr., triangular-lanceoladas a subuladas, coniventes ou contortas no fruto. Corola hipocrateriforme, lilás, externamente glabra, tubo 7-12 mm compr., limbo 9-10 mm diâm. Par superior de estames com apêndices conectivais que superam as tecas, exsertos. Estilete 7-10 mm compr.; ovário ca. $1 \mathrm{~mm}$ compr. Clusas 2,5-6 mm compr., ápice agudo ou obtuso, base alargada ou não alargada, face ventral papilosa, face dorsal com a porção superior reticulada e a inferior estriada.

Ocorre no Brasil, Argentina e Uruguai, sendo comum em solos arenosos (Troncoso 1964; Múlgura 2007). Possui ampla distribuição no Estado. Ver comentários em $G$. aristigera, G. catharinae e G. selloi. Floresce e frutifica de agosto a março.

Material examinado selecionado: BRASIL. Rio Grande do Sul: Caçapava do Sul, 16/IX/1998, fl. fr., A. Knob e S. Bordignon 5674 (UNILASALLE); Ibirubá, 3/X/2007, fl. fr., V. Thode 67 (ICN); Pareci Novo, 17/VIII/1949, fl., $B$. Rambo 42959 (PACA); Pinhal da Serra, 30/VIII/2000, fl., G. Spanholi s.n. (HUCS 18722); Rio Grande, 24/X/2007, fl. fr., L. Eggers 291 (ICN); Rio Pardo, 20/X/2007, fl. fr., V. Thode 100 (ICN); Vacaria, 5/XI/2007, fl. fr., R. Lüdtke 775 (ICN).

25. Glandularia tessmannii (Moldenke) P. Peralta \& Thode, Rodriguésia 61(1): S30. 2010.

Fig. 208-214

Ervas rasteiras, radicantes nos nós, com $10-50 \mathrm{~cm}$ compr. Caule híspido, com tricomas tectores e glandulares pedicelados em várias direções, a maioria patentes; entrenós 1-5 cm compr. Folhas inteiras; lâmina $1-4 x 0,7-1,5 \mathrm{~cm}$, ovalada a oval-lanceolada, ápice agudo, base aguda a obtusa, decurrente no pecíolo, margem serreada a dentada; face adaxial estrigosa, com tricomas tectores bem distribuídos, face abaxial estrigosa, com tricomas tectores mais evidentes sobre as nervuras; pecíolo 2-5 mm compr. Inflorescências em monobótrios; florescências $2 \times 3 \mathrm{~cm}$, em espigas multifloras, umbeliformes na antese, com raque alongada até $5 \mathrm{~cm}$ na frutificação; pedúnculo das florescências híspido, com tricomas tectores e glandulares pedicelados em várias direções, a maioria patentes. Brácteas 7-8 mm compr., lanceoladas, pilosas, com tricomas tectores e glandulares pedicelados principalmente sobre a nervura mediana, margem ciliada. Cálice 12-13 mm compr., híspido, com tricomas tectores e glandulares pedicelados patentes e antrorsos, principalmente sobre as costelas; lacínias $0,5-1,5 \mathrm{~mm}$ compr., triangularlanceoladas. Corola hipocrateriforme, rosa a lilás, tubo 18-20 mm compr., limbo 8-12 mm diâm., com tricomas glandulares externamente. Par superior de estames sem apêndices conectivais. Estilete 15-17 mm compr.; ovário ca. $1 \mathrm{~mm}$ compr. Clusas não vistas.

Também é encontrada nos estados de Santa Catarina e Paraná, sendo esta a primeira citação para o Rio Grande do Sul. O único exemplar encontrado foi coletado no Litoral. Pode ser confundida com G. peruviana, porém esta possui 


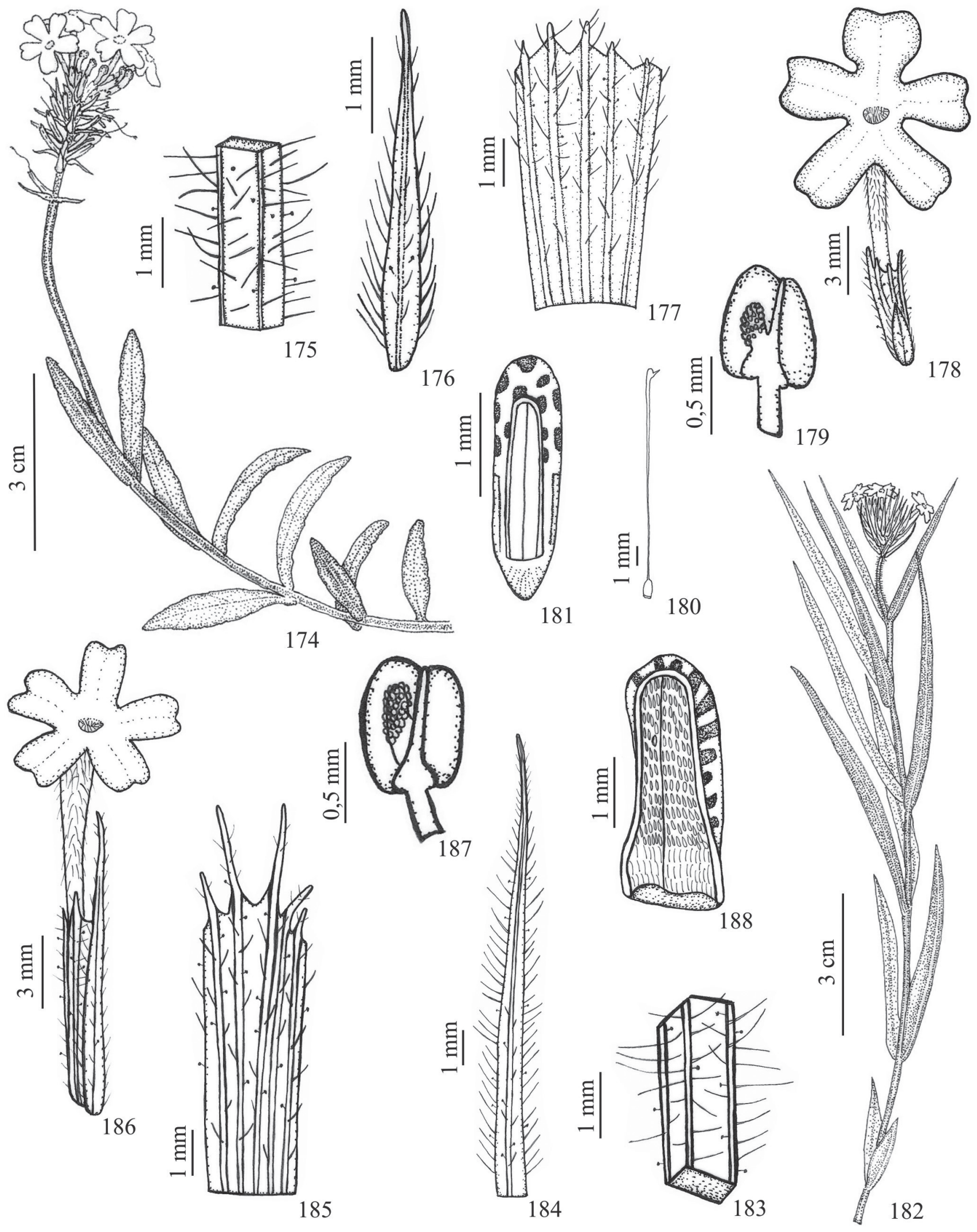

Figuras 174-181. Glandularia sessilis (Cham.) Tronc. 174. Aspecto geral da planta. 175. Indumento do pedúnculo das florescências. 176. Bráctea. 177. Cálice aberto. 178. Flor. 179. Antera do par superior de estames com apêndice no conectivo, vista dorsal. 180. Gineceu. 181. Clusa, vista ventral ( $V$. Thode 202). Figuras 182-188. Glandularia stellarioides (Cham.) Schnack \& Covas. 182. Ramo (B. Rambo 10156). 183. Indumento do pedúnculo das florescências. 184. Bráctea. 185. Cálice aberto. 186. Flor. 187. Antera do par superior de estames com apêndice no conectivo, vista dorsal. 188. Clusa, vista ventral (B. Rambo 9758$)$. 


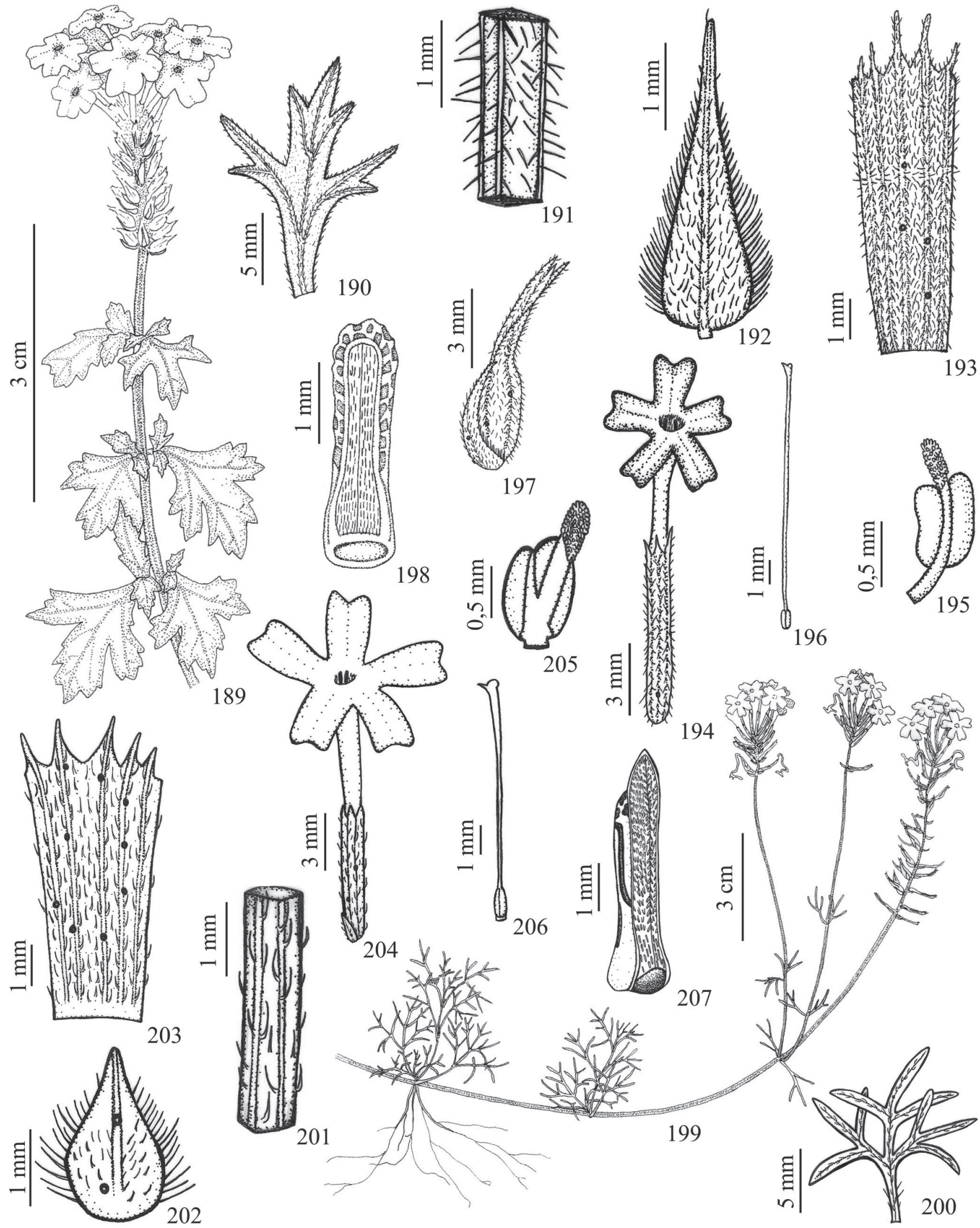

Figuras 189-198. Glandularia subincana Tronc. 189. Ramo (A. Schneider et al. 1614). 190. Folha, face abaxial. 191. Indumento do pedúnculo das florescências. 192. Bráctea. 193. Cálice aberto. 194. Flor. 195. Antera do par superior de estames com apêndice no conectivo, vista dorsal. 196. Gineceu. 197. Cálice frutífero com bráctea. 198. Clusa, vista ventral (V. Thode 191). Figuras 199-207. Glandularia tenera (Spreng.) Cabrera. 199. Ramo (P. Brack 653). 200. Folha, face abaxial. 201. Indumento do pedúnculo das florescências. 202. Bráctea. 203. Cálice aberto. 204. Flor. 205. Antera do par superior de estames com apêndice no conectivo, vista dorsal. 206. Gineceu. 207. Clusa, vista lateral (L. Eggers 291). 
corola vermelha e pilosa, com tricomas tectores externamente e G. tessmannii possui corola rosa a lilás, com tricomas glandulares externamente. Floresce em outubro.

Material examinado: BRASIL. Rio Grande do Sul: Arroio do Sal, 20/X/1990, fl., M.G. Rossoni 546 (ICN).

\section{Glandularia thymoides (Cham.) N. O'Leary, Novon 17(4): 509. 2007.}

Fig. 215-224

Ervas ou subarbustos eretos a prostrados, com 12-50 $\mathrm{cm}$ alt. Caule estrigoso, com tricomas tectores adpressos e antrorsos; entrenós 0,3-2,6 cm compr. Folhas pinatissectas, trissectas, podendo ter os segmentos laterais bi ou tripartidos, lineares; lâmina $0,4-2 \times 0,4-0,8 \mathrm{~cm}$; face adaxial estrigosa, com tricomas tectores adpressos principalmente próximos à nervura central e margem, face abaxial estrigosa, com tricomas tectores adpressos bem distribuídos e tricomas glandulares pedicelados; folhas sésseis. Inflorescências em monobótrios ou pleiobótrios heterotéticos com 1 ou 2 pares de paracládios simples; florescências 0,6-1,2x0,6-1,5 $\mathrm{cm}$, em espigas multifloras ou paucifloras, ovóides a umbeliformes na antese, com raque alongada na frutificação até $3 \mathrm{~cm}$; pedúnculo das florescências estrigoso, com tricomas tectores adpressos e antrorsos. Brácteas 2-3,5(5) mm compr., ovaladas, subglabras a estrigosas, com tricomas tectores e glandulares pedicelados, margem ciliada. Cálice 4-7 mm compr., estrigoso, com tricomas tectores adpressos antrorsos, bem distribuídos; lacínias 0,5-1 mm compr., triangularlanceoladas, coniventes no fruto. Corola infundibuliforme, azul a lilás, externamente pilosa, tubo 4,1-7 mm compr., limbo 3,5 mm diâm. Par superior de estames sem apêndices conectivais, ou estes vestigiais, que não superam as tecas, inclusos. Estilete $2 \mathrm{~mm}$; ovário ca. $0,7 \mathrm{~mm}$ compr. Clusas 1,7-2,5 mm compr., ápice obtuso, base não alargada, face ventral papilosa, face dorsal com a porção superior reticulada e a inferior estriada.

Ocorre no Paraguai, Argentina (Províncias de Misiones, Corrientes e Entre Ríos), Uruguai (Múlgura 2007) e no Brasil, nos estados do Mato Grosso do Sul, Paraná, Santa Catarina e Rio Grande do Sul, onde é geralmente encontrada na Campanha, Serra do Sudeste, Depressão Central, Litoral Norte e Campos de Cima da Serra, geralmente em campos de solos arenosos e pedregosos. Difere das demais espécies principalmente por suas folhas trissectas e sésseis. Floresce e frutifica de agosto a maio.

Material examinado selecionado: BRASIL. Rio Grande do Sul: Bagé, VIII/1987, fl., M. Sobral et al. 5712 (ICN); Caçapava do Sul, 20/X/2007, fl. fr., V. Thode 104 (ICN); Caxias do Sul, 5/I/1946, fl. fr., B. Rambo 31077 (PACA); Ijuí, 7/II/1956, fl. fr., Pivetta 1135 (PACA); Porto Alegre, 2/X/1948, fl., B. Rambo 37827 (PACA); São Borja, 5/ XII/2007, fl., V. Thode 189 (ICN); São José dos Ausentes, 18/XI/2007, fl. fr., V. Thode 148 (ICN); Torres, 26/IV/1975, fl., A.A. Filho s.n. (SMDB 1180).
27. Glandularia tomophylla (Briq.) P. Peralta, Darwiniana 45(2): 241. 2008.

Fig. 225-234

Ervas prostradas, com 12-35 cm compr. Caule híspido, com tricomas tectores retrorsos; entrenós $1-4 \mathrm{~cm}$ compr. Folhas inteiras, pinatissectas, podendo ter os lobos divididos ou não em 2 ou mais segmentos oblongos ou obovados; lâmina 1-5x0,6-3,5 cm, decurrente no pecíolo; face adaxial estrigosa, com tricomas tectores bem distribuídos, face abaxial estrigosa, com tricomas tectores mais evidentes sobre as nervuras, com ou sem tricomas glandulares subsésseis; pecíolo 2-5 mm compr. Inflorescências em monobótrios ou pleiobótrios heterotéticos com 1 par de paracládios simples; florescências 1,5-2x2-2,5 cm, em espigas multifloras, umbeliformes na antese, com raque alongada na frutificação até $6 \mathrm{~cm}$; pedúnculo das florescências híspido, com tricomas tectores retrorsos. Brácteas 3-6 mm compr., lanceoladas, pilosas, com tricomas tectores, com ou sem tricomas glandulares subsésseis, margem ciliada. Cálice 8-10 mm compr., piloso, com tricomas tectores retrorsos e patentes, bem distribuídos, e tricomas glandulares subsésseis; lacínias 0,8-1,8 mm compr., triangular-lanceoladas, coniventes no fruto. Corola hipocrateriforme, lilás, externamente pilosa, tubo 10-12 mm compr., limbo 7 mm diâm. Par superior de estames com apêndices conectivais que superam as tecas, exsertos. Estilete 10-11 mm compr.; ovário ca. $1 \mathrm{~mm}$ compr. Clusas 2-3 mm compr., ápice obtuso, base não alargada, face ventral lisa a papilosa, face dorsal com os dois terços superiores reticulados e o restante estriado.

Encontrada no Paraguai e Argentina, nas Províncias de Misiones, Corrientes e Formosa (Múlgura 2007), sendo esta a primeira citação para o Rio Grande do Sul, onde foi encontrada nas Missões e Planalto Médio, em campos, terrenos arenosos e beiras de estrada. Ver comentários em G. subincana. Floresce e frutifica de setembro a fevereiro.

Material examinado selecionado: BRASIL. Rio Grande do Sul: São Borja, 6/XII/2007, fl. fr., V. Thode 201 (ICN); São Francisco de Assis, 9/II/1990, fl. fr., D.B. Falkenberg et al. 5093 (ICN); Tupanciretã, 3/X/2007, fl. fr., V. Thode 77 (ICN).

\section{Agradecimentos}

À Coordenação de Aperfeiçoamento de Pessoal de Nível Superior (CAPES), pela bolsa de mestrado concedida à primeira autora; ao Programa de Pós-Graduação em Botânica-UFRGS, pelo apoio institucional; aos curadores e funcionários dos herbários consultados; à Maria E. Múlgura e Paola Peralta, por suas colaborações e ao Edson Soares, pela elaboração das ilustrações do aspecto geral das plantas.

\section{Referências bibliográficas}

Atkins, S. 2004. Verbenaceae. Pp. 449-468. In: Kadereit, J. The Families and Genera of Vascular Plants. VII. Flowering Plants: Dicotyledons: Lamiales (except Acanthaceae including Avicenniaceae). Berlin, Springer. Botta, S.M. 1989. Estudios en el género sudamericano Junellia (Verbenaceae-Verbenoideae) 1. Delimitación y tratamiento infragenérico. Darwiniana 29(1-4): 371-396. 


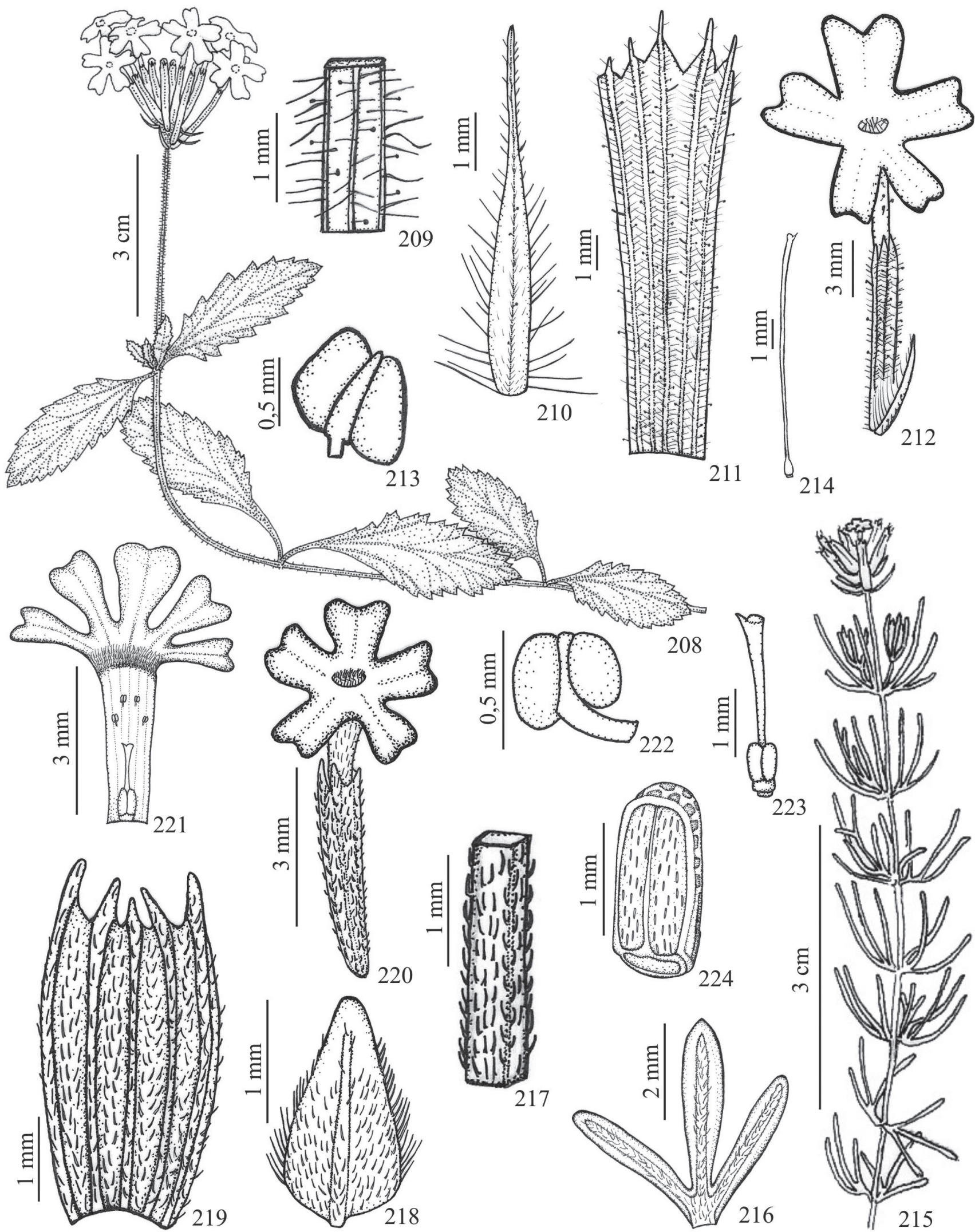

Figuras 208-214. Glandularia tessmannii (Moldenke) P. Peralta \& Thode. 208. Ramo. 209. Indumento do pedúnculo das florescências. 210. Bráctea. 211. Cálice aberto. 212. Flor. 213. Antera do par superior de estames, vista dorsal. 214. Gineceu (M.G. Rossoni 546). Figuras 215-224. Glandularia thymoides (Cham.) N. O’Leary. 215. Ramo (E. Boldo 4). 216. Folha, face abaxial. 217. Indumento do pedúnculo das florescências. 218. Bráctea. 219. Cálice aberto. 220. Flor. 221. Flor aberta. 222. Antera do par superior de estames, vista dorsal. 223. Gineceu. 224. Clusa, vista ventral (V. Thode 148). 

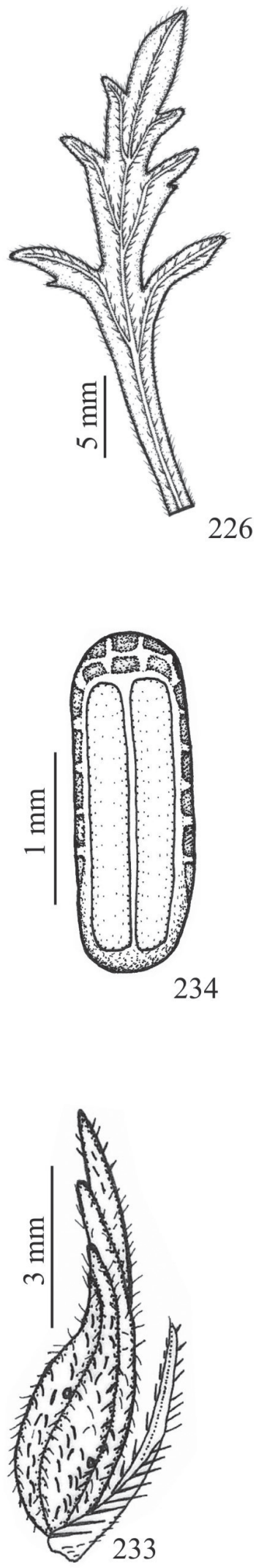

234
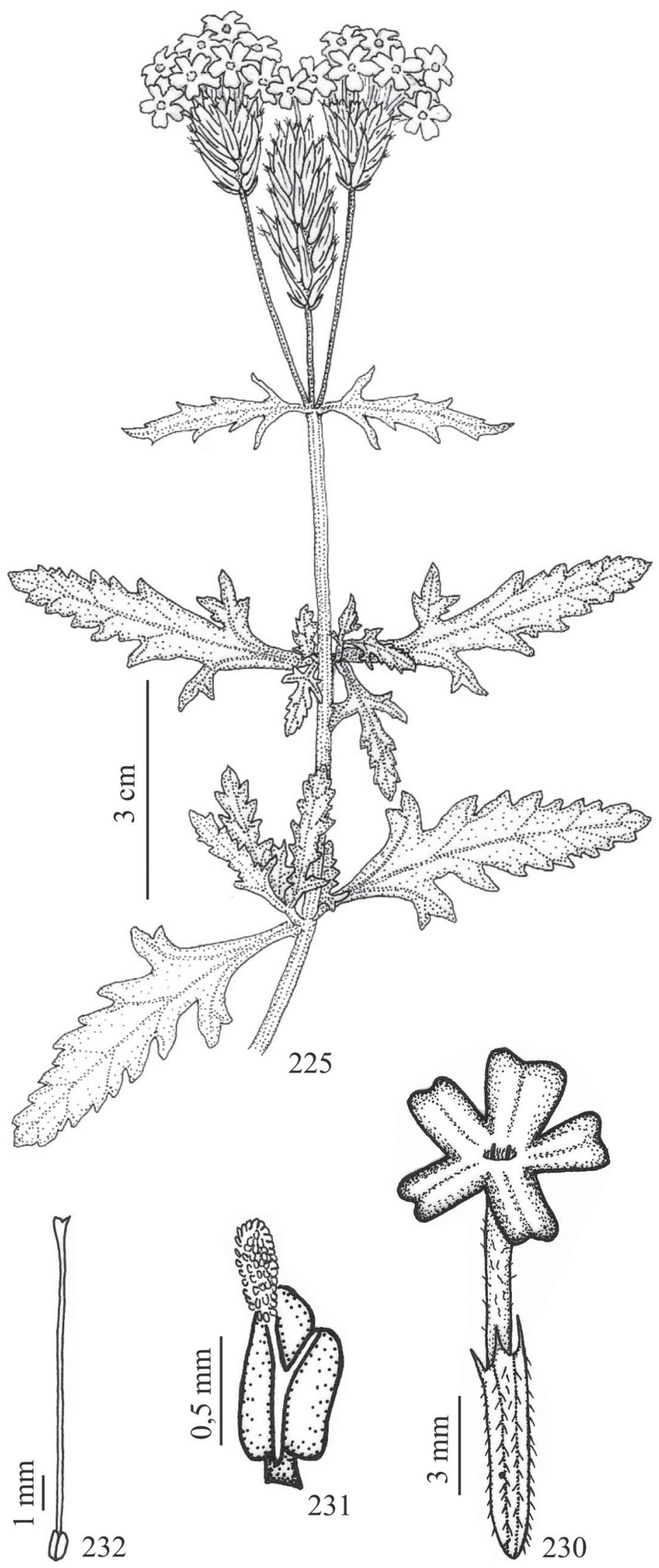

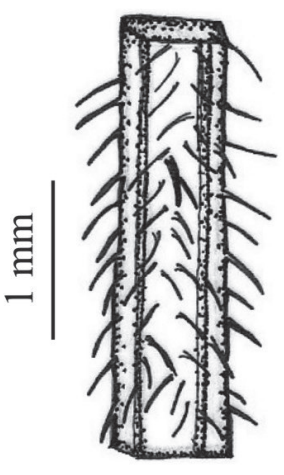

227

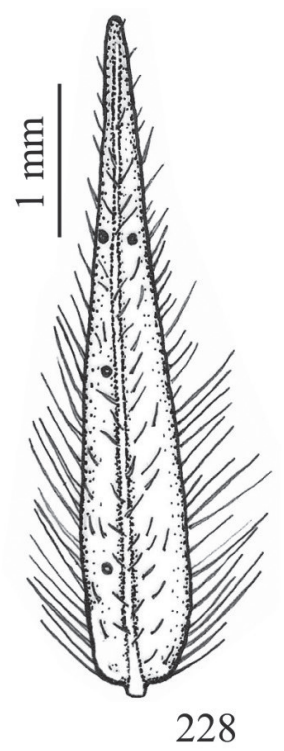

Figuras 225-234. Glandularia tomophylla (Briq.) P. Peralta. 225. Aspecto geral da planta. 226. Folha, face abaxial. 227. Indumento do pedúnculo das florescências. 228. Bráctea. 229. Cálice aberto. 230. Flor. 231. Antera do par superior de estames com apêndice no conectivo, vista dorsal. 232. Gineceu. 233. Cálice frutífero com bráctea. 234. Clusa, vista ventral (V. Thode 77). 
Botta, S.M. 1993. Notas en el género Glandularia (Verbenaceae-Verbenoideae) III. Estudio taxonómico de las especies patagónicas. Parodiana 8(1): 9-36.

Brummitt, R.K. \& Powell, C.E. 1992. Authors of plant names. Kew, The Royal Botanic Gardens.

Font Quer, P. 1977. Diccionario de Botánica. Barcelona, Labor.

Fortes, A.B. 1959. Geografia física do Rio Grande do Sul. Porto Alegre, Globo.

Holmgren, P.K.; Holmgren, N.H. \& Barnett, L.C. 2008. Index Herbariorum on the Internet. Disponível em: $<$ http://sciweb.nybg.org/science2/IndexHerbariorum.asp (Acesso em: 11/2008).

Lombardo, A. 1983. Flora montevidensis. v. 2. Pp. 43-56. Montevideo, Intendencia Municipal de Montevideo.

Martínez, S. \& Múlgura, M.E. 1996. Morfología de las inflorescências en Verbenaceae-Verbenoideae I: Tribu Verbenae. Darwiniana 34(1-4): $1-17$.

Múlgura, M.E. 2007. Verbenaceae. In: Zuloaga, F.O. \& Morrone, O. Catálogo de las Plantas Vasculares de la República Argentina II. Pp. 1-34 www.darwin.edu.ar/Publicaciones/CatalogoVascII/ CatalogoVascII. asp (Acesso em: 08/2007)

O'Leary, N. \& Peralta, P. 2007. Nuevas combinaciones en el género Glandularia (Verbenaceae). Darwiniana 45(2): 218-230.

O’Leary, N.; Múlgura, M.E. \& Morrone, O. 2007. New combinations in South American Glandularia (Verbenaceae). Novon 17(4): 503-511.

O’Leary, N.; Yuan, Y.; Chemisquy, A. \& Olmstead, R.G. 2009. Reassignment of species of paraphyletic Junellia s.l. to the new genus Mulguraea (Verbenaceae) and new circumscription of genus Junellia: molecular and morphological congruence. Systematic Botany 34(4): 777-786.

Peralta, P. \& Thode, V. 2010. Una nueva especie, un nuevo status y nuevas combinaciones en Glandularia (Verbenaceae) para el Sur de Brasil. Rodriguésia 61(1): S29-S32.

Schnack, B. \& Covas, C. 1944. Nota sobre la validez del gênero Glandularia. Darwiniana 6: 469-476.

Schnack, B. \& Covas, C. 1964. Bases naturales de la separacion genérica de Verbena y Glandularia (Verbenáceas). Notas de la Comisión de Investigación Científica. La Plata 2(2): 3-12.
Solbrig, O.T. 1968. Artificial hybridization between different polyploid levels in Glandularia (Verbenaceae). American Journal of Botany 55(10): 1235-1239.

Stearn, W.T. 2000. Botanical Latin. 4 ed. Portland, Timber Press.

Troll, W. 1950. Über den Infloreszenzbegriff und seine Anwendung auf die krautige Region blühender Pfanzen. Abhandlungen. Akademie der Wissenschaften und der Literatur, Mainz. MathematischNaturwissenschaftliche Kl. $\mathbf{n}^{\circ} \mathbf{1 5}$.

Troll, W. 1957. Pflanzenmorphologie II: Die blühende Pflanze. Jena, Gustav Fischer.

Troll, W. 1964. Die Infloreszenzen. Typologie und Stellung im Aufbau des Vegetationskörpers. I. Stuttgart, Gustav Fischer.

Troll, W. 1969. Die Infloreszenzen. Typologie und Stellung im Aufbau des Vegetationskörpers. II. Stuttgart, Gustav Fischer.

Troncoso, N.S. 1964. Dilucidación de las espécies platenses de Glandularia (Verbenáceas) de hojas disectas. Darwiniana 13(2-4): 468-485.

Troncoso, N.S. 1971. Aclaración sobre Glandularia megapotamica (Spr.) Cabr. et Daws. y sus especies afines (Verbenaceae). Darwiniana 16(3-4): 613-621.

Troncoso, N.S. 1974. Los Géneros de Verbenáceas de Sudamérica extratropical. Darwiniana 18(3-4): 295-412.

Troncoso, N.S. 1979. Verbenaceae. Pp. 229-294. In: A. Burkart. Flora Ilustrada de Entre Rios (Argentina). v. 6, pt. 5. Buenos Aires, INTA.

Umber, R.E. 1979. The Genus Glandularia (Verbenaceae) in North America. Systematic Botany 4(1): 72-102.

Weberling, F. 1961. Die Infloreszenzen der Valerianaceen und ihre systematische Bedeutung. Abhandlungen. Akademie der Wissenschaften und der Literatur, Mainz. Mathematisch-Naturwissenschaftliche Kl. $\mathbf{n}^{0} 5$.

Weberling, F. 1965. Typology of Inflorescences. Journal of the Linnaean Society of Botany 59: 215-221.

Weberling, F. 1985. Aspectos modernos de la morfología de las inflorescencias. Boletín de la Sociedad Argentina de Botánica 24(1-2): 1-28.

Yuan, Y. \& Olmstead, R.G. 2008. A species-level phylogenetic study of the Verbena complex Verbenaceae) indicates two independent intergeneric chloroplast transfers. Molecular Phylogenetics and Evolution 48(1): 23-33. 